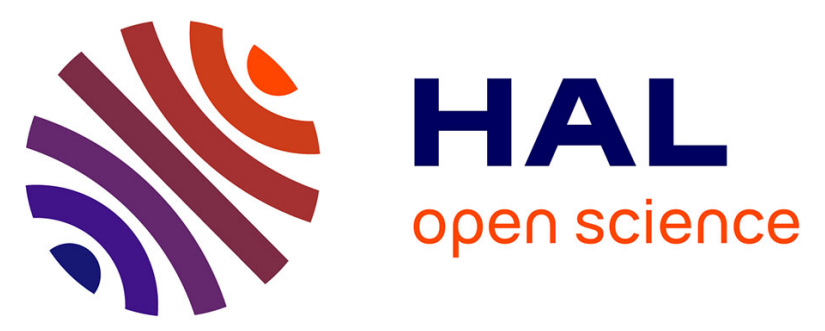

\title{
The effect of thermal treatment on structure and surface composition of PtCo electro-catalysts for application in PEMFCs operating under automotive conditions
}

\author{
A. Stassi, I. Gatto, G. Monforte, V. Baglio, E. Passalacqua, V. Antonucci,
} A.S. Arico'

\section{To cite this version:}

A. Stassi, I. Gatto, G. Monforte, V. Baglio, E. Passalacqua, et al.. The effect of thermal treatment on structure and surface composition of PtCo electro-catalysts for application in PEMFCs operating under automotive conditions. Journal of Power Sources, 2012, pp.35-45. hal-00753348

\author{
HAL Id: hal-00753348 \\ https://hal.science/hal-00753348
}

Submitted on 19 Nov 2012

HAL is a multi-disciplinary open access archive for the deposit and dissemination of scientific research documents, whether they are published or not. The documents may come from teaching and research institutions in France or abroad, or from public or private research centers.
L'archive ouverte pluridisciplinaire HAL, est destinée au dépôt et à la diffusion de documents scientifiques de niveau recherche, publiés ou non, émanant des établissements d'enseignement et de recherche français ou étrangers, des laboratoires publics ou privés. 


\title{
The effect of thermal treatment on structure and surface composition of PtCo
}

\section{electro-catalysts for application in PEMFCs operating under automotive applications}

\author{
A. Stassi, I. Gatto, G. Monforte, V. Baglio, E. Passalacqua, V. Antonucci, A. S. Aricò* \\ CNR-ITAE Istituto di Tecnologie Avanzate per l'Energia "Nicola Giordano”
}

Via Salita S. Lucia sopra Contesse 5, 98126 Messina, Italy

\section{Abstract}

The structural and surface characteristics of carbon-supported PtCo cathode electro-catalysts were investigated to evaluate their performance and resistance to degradation under high temperature $(\sim 110$ $\left.{ }^{\circ} \mathrm{C}\right)$ operation in a polymer electrolyte membrane fuel cell (PEMFC). Two different thermal treatments were investigated i.e. $600^{\circ}$ and $800{ }^{\circ} \mathrm{C}$ corresponding to the occurrence of a disordered face-centered cubic (fcc) structure and a primitive cubic ordered $\left(\mathrm{L1}_{2}\right)$ phase. The specific colloidal preparation route and carbothermal reduction allowed to obtain a similar mean crystallite size, i.e. 2.9 and $3.3 \mathrm{~nm}$ for the catalysts after the treatment at $600^{\circ}$ and $800{ }^{\circ} \mathrm{C}$, as well as a suitable degree of alloying. Both electrocatalysts were subjected to the same pre-leaching procedure to modulate the surface characteristics. The surface properties were investigated by X-ray photoelectron spectroscopy (XPS) and low-energy ion scattering spectroscopy (LE-ISS, $3 \mathrm{He}^{+}$at $1 \mathrm{kV}$ ). Occurrence of Pt segregation in the outermost surface layers and similar electronic properties in the materials were observed. Both catalysts showed good performance under PEMFC operation; however, the catalyst characterised by the disordered fcc structure performed slightly better at low temperature $\left(80{ }^{\circ} \mathrm{C}\right)$ and full humidification; whereas, the primitive cubic ordered structure catalyst showed superior characteristics both in terms of performance and stability at high temperature $\left(110^{\circ} \mathrm{C}\right)$ and low R.H. which are the operating conditions more relevant for automotive applications. The enhanced stability of the catalyst characterised by primitive cubic ordered structure is attributed to the growth of a stable Pt-oxide layer

\footnotetext{
* Corresponding author. Tel.: +39 090624237; fax: +39 090624247. E-mail address: arico@itae.cnr.it (A.S. Arico).
} 
during operation at high temperature and low R.H. which hinders sintering and dissolution processes at the catalyst surface.

Key-words: PtCo catalysts, Oxygen reduction, Polymer electrolyte membrane fuel cells, High temperature, Automotive applications, Surface properties. 


\section{Introduction}

One of the main limitations of current polymer electrolyte membrane fuel cells is the sluggishness of oxygen reduction reaction (ORR) in the potential region close to the reversible potential [1-2]. In general, the electrochemical processes involved in PEMFCs need Pt-based electro-catalysts to occur at significant rates [3-4]. Several methods to improve the electrocatalytic activity of Pt-based catalysts are being actively investigated by either tailoring the particle size or alloying Pt with transition metals [57]. Pt utilisation can be enhanced by increasing either its dispersion on the support or the interfacial region with the electrolyte. Under practical conditions, mass activity (MA), i.e. the current normalised by the Pt loading, reaches a maximum for Pt and Pt alloy catalysts with a mean particle size of approximately $3 \mathrm{~nm}[5,8]$. On the other hand, specific activity (SA), i.e. the current normalised by the electrochemical active surface area (ECSA), increases gradually with an increase in Pt particle size [5]. Enhancement in electrocatalytic activity for oxygen reduction by alloying Pt with transition metals has been interpreted differently; several studies have addressed the analysis of bulk and surface properties of proposed alloy combinations. Electrocatalytic effects have been ascribed to factors such as interatomic spacing, preferred orientation, and electronic interactions [7-11]. The state of understanding of the factors determining electrocatalytic activity increased recently with the investigation of the surface characteristics of extended Pt-alloy model surfaces in UHV and through the investigation of oxygen adsorption features by density functional theory studies (DFT) [12-15].

It was observed that extended alloys which are surface enriched in Pt show enhanced ORR and are characterised by increased stability $[12-14,16]$. The occurrence of transition metals such as $\mathrm{Co}, \mathrm{Ni}, \mathrm{Fe}$ on the top-most catalyst surface layers reduces the number of active sites for the ORR and may cause membrane contamination by releasing the corresponding cations upon dissolution [17-23]. Dissolution and re-precipitation on larger particles (Ostwald ripening) is considered one of the most common degradation phenomena occurring for PEMFC cathodes $[18,19]$. On the other hand, the activity 
enhancement in the presence of Pt segregation has been initially attributed by Watanabe et al. [16] to an increase of d-electron vacancies in the Pt-enriched surface layer caused by the underlying transition metal. This should result in weakened O-O bonds. More recently, Markovic et al. [14] suggested the occurrence of a lowered Pt valence band center relative to the Fermi level in Pt-skin layer based alloys caused by the underlying transition metal. This effect is determined both by an electronic ligand effect and the decreased Pt-Pt distance in the surface atomic structure. Such effects should cause a weakening of the metal-oxygen strength which may favour an easier desorption of reaction intermediates.

From a practical point of view, the procedures that can produce an enrichment of $\mathrm{Pt}$ on the outermost layers of both extended alloy surfaces and supported nanoparticles are an induced surface segregation by high-temperature annealing and removal of the less noble transition metal from the alloy surface by pre-leaching in an appropriate acid. As reported in the literature [24-28], pre-leaching usually results in a better electrochemical activity. After these treatments, different surface structures may occur such as a Pt skin layer which is a compact top surface layer of pure Pt, a skeleton structure that is the occurrence of a strong Pt enrichment on a corrugated surface, the percolated or sandwichsegregation structure where the Pt enrichment on the surface is accompanied by a depletion of $\mathrm{Pt}$ in the second layer and composition oscillation in the core layers. Most of these evidence derive from the UHV analysis of bulk alloys. However, surface characteristics of carbon supported Pt-alloy nanoparticles subjected to acid leaching may considerable deviate from those envisaged by UHV studies of extended Pt alloy model surfaces. Accordingly, several attempts have been made recently to use analytical tools directly on practical carbon supported Pt-alloy nanoparticles to investigate the near surface compositions [24, 29]. Shao-Horn et al. have used aberration-corrected high-angle annular dark-field (HAADF) scanning transmission electron microscopy to investigate the composition of $\mathrm{Pt}_{3} \mathrm{Co}$ nanoparticles on an atomic scale [24]. Percolated and core-shell structures as well as surface $\mathrm{Pt}$ segregation have been revealed for the supported nanoparticles. Although this approach provides 
excellent information on the single nanocrystal, one of the limitations appears to be related to the fact that it provides a local information concerning with a few selected nanoparticles that may be not representative of the overall sample. In other words, the sample volume that is investigated at the atomic level by electron microscopy is quite small and thousands of nanoparticles in different regions should be examined to provide an information that may be considered statistically representative. In a recent study in our group [29], we have used Low-energy ion $\left(3 \mathrm{He}^{+}\right)$scattering spectroscopy (LE-ISS) to get information about the chemical composition of the outermost atomic layers in practical carbon supported Pt-alloy nanoparticle catalysts. The analysis region with this technique is typically several millimetres wide and several analyses in different sample regions may provide a statistically relevant information about the top-most surface composition of the sample.

Another aspect worth mentioning is that most of the studies addressing the correlation of structural and surface characteristics with the ORR activity report electrochemical results obtained by rotating disc electrodes (RDE) in acidic liquid electrolytes. From such an approach, several conjectures are thus made regarding the effective perspectives of the advanced electrocatalysts under real fuel cell operation. Whereas it is of relevant practical interest to correlate the structural and surface properties to the mass activity directly measured under fuel cell conditions to clear understand the effective level of enhancement that may be achieved with the novel nanoparticle structures [29]. For a practical application, the electrocatalytic activity is not the only parameter determining the successful utilization of an electrocatalyst; aspects related to mass transport characteristics and electrochemical stability are of similar importance. Moreover, since the electrochemical reactions occur at the catalyst surfaceelectrolyte interface, the ORR behaviour is not only determined by intrinsic catalyst characteristics but also by a proper matching of electrocatalyst and electrolyte properties. Thus, the role of surface composition and structure that are recognised to govern the activity and stability need to be related to the specific electrolyte and operating conditions which are relevant for fuel cell applications. 
Recent advances in fuel cells technology demand operation at high working temperatures to improve efficiency, tolerance of contaminants and for an easy water management [2]. The limited availability of polymer electrolyte membranes that can operate efficiently under conditions relevant to automotive applications (e.g. $110^{\circ}-130^{\circ}$ C, R.H. $<33 \%$ [2]) has also restricted the number of electrocatalytic investigations under such conditions [17, 29]. Since PEMFCs for automotive applications are essentially based on perfluorosulphonic acid membranes (PFSA) it appears important to determine the catalytic activity and stability in the presence of such benchmark electrolytes. Since a wide number of research groups is actively involved in improving and modifying these polymer electrolytes for operation under conditions useful for the automotive application [30-32], it also appears appropriate to analyse the behaviour of electro-catalysts under conditions similar to the target application for electrotraction [17]. We have overcome the constraints related to the dehydration behaviour at high temperature of benchmark Nafion membranes by carrying experiments under pressurised conditions. Although, the operating conditions may not exactly reproduce those aimed by the automakers, i.e. almost ambient pressure [33], the present approach may provide a basis to compare catalytic activity and stability under conditions which are as close as possible to the practical automotive application.

With regard to the catalyst preparation we have used a colloidal deposition method, carbothermal reduction at different temperatures and a pre-leaching procedure to enrich $\mathrm{Pt}$ in the outermost catalyst layers of PtCo alloys. As observed in the literature, for extended Pt alloy surfaces [12-14], the segregation of $\mathrm{Pt}$ on the surface has the role of maintaining the electronic properties of the alloy while avoiding any occurrence of the electropositive element on the surface that could dissolve into the electrolyte. In this work, we have specifically addressed our efforts to examine the role of the thermal treatment in determining the occurrence of possible different surface compositions and structures and we have analysed the resulting effects on catalytic activity and stability in PEMFCs operating in a wide range of conditions including those relevant for automotive applications. 


\section{Experimental}

\subsection{Catalyst Preparation}

A 50 wt. \% Pt-Co/C catalyst with nominal alloy composition $\mathrm{Pt}_{3} \mathrm{Co}_{1}$ (at.) was prepared by incipient wetness from cobalt nitrate that was adsorbed on an amorphous PtOx/C catalyst [26]. The concentration of $\mathrm{Co}\left(\mathrm{NO}_{3}\right)_{2}$ was adjusted to achieve a $\mathrm{Pt} / \mathrm{Co}$ atomic ratio of about 3:1 in the final catalysts. The PtOx/C was prepared by using a sulphite complex route [34]. Ketjenblack EC (KB) carbon black with BET surface area of $850 \mathrm{~m}^{2} \mathrm{~g}^{-1}$ was used as conductive support for the PtCo nanoparticles. After the cobalt impregnation step, a high temperature carbothermal reduction in inert (Ar) atmosphere was carried out to form the carbon-supported PtCo alloy. Two specific temperatures were selected for the thermal reduction $\left(600^{\circ}\right.$ and $\left.800{ }^{\circ} \mathrm{C}\right)$ since it was preliminarily observed that different structural properties for the catalysts are correspondingly achieved (see below). A preleaching procedure at $80{ }^{\circ} \mathrm{C}$ in $0.5 \mathrm{M} \mathrm{HClO}_{4}$ was carried out for the PtCo catalysts after the thermal reduction.

\subsection{Physico-Chemical Analysis}

The catalysts were characterised by X-ray diffraction (XRD) using a Philips X-pert 3710 X-ray diffractometer with $\mathrm{Cu} \mathrm{Ka}$ radiation operating at $40 \mathrm{kV}$ and $30 \mathrm{~mA}$. The peak profile of the (220) reflection in the face centered cubic structure of Pt and Pt-alloy was analysed by using the Marquardt algorithm and it was used to calculate the crystallite size by the Debye-Scherrer equation [26]. Instrumental broadening was determined by using a standard platinum sample. X-ray fluorescence analysis of the catalysts was carried out by a Bruker AXS S4 Explorer spectrometer operating at a power of $1 \mathrm{~kW}$ and equipped with a $\mathrm{Rh} \mathrm{X}$-ray source, a $\mathrm{LiF} 220$ crystal analyzer and a $0.12^{\circ}$ divergence collimator. The Pt/Co atomic ratio for the alloy was determined by XRD analyis using the Vegard's law. The overall Pt/Co ratio in the catalysts (both alloyed and unalloyed) was determined by XRF. The total metal content in the catalysts was determined by burning the carbon support in a 
thermal gravimetry experiment up to $950{ }^{\circ} \mathrm{C}$ in air and subsequent XRD analysis. Table 1 shows the main bulk physico-chemical characteristics of the carbon supported $\mathrm{Pt}-\mathrm{Co}$ catalysts. Transmission electron microscopy (TEM) analysis was made by first dispersing the catalyst powder in isopropyl alcohol. A few drops of these solutions were deposited on carbon film-coated $\mathrm{Cu}$ grids and analysed with a FEI CM12 microscope.

X-ray photoelectron spectroscopy (XPS) measurements were performed by using a Physical Electronics (PHI) 5800-01 spectrometer. A monochromatic Al K $\alpha$ X-ray source was used at a power of 350 W. Spectra were obtained with pass energies of $58.7 \mathrm{eV}$ for elemental analysis (composition) and $11.75 \mathrm{eV}$ for the determination of the oxidation states. The pressure in the analysis chamber of the spectrometer was $1 \cdot 10^{-9}$ Torr during the measurements. The Ag $3 d_{5 / 2}$ peak of an Ag foil was taken, after argon sputtering, for checking the calibration of the binding energy (BE) scale. The quantitative evaluation of each peak was obtained by dividing the integrated peak area by atomic sensitivity factors, which were calculated from the ionization cross-sections, the mean free electron escape depth and the measured transmission functions of the spectrometer. XPS data have been interpreted by using the online library of oxidation states implemented in the PHI MULTIPAK 6.1 software and the PHI Handbook of X-ray photoelectron spectroscopy [35]. Deconvolution of XPS spectra was carried out by using the MULTIPAK software.

For LE-ISS measurements, the polarity of the analyzer in the PHI 5800-01 spectrometer was switched from XPS to ISS mode, a 3He-feed ion gun operating at low voltage $(1 \mathrm{kV})$ was used. LE-ISS measurements were carried out by analyzing the energy of the scattered $3 \mathrm{He}^{+}$ions at a scattering angle of 134.80 degrees. A flat sample of catalyst powder was deposited on the sample holder which was tilted at $45^{\circ}$ with respect to the analyzer. While the analysis chamber was under differential pumping, the sample surface was sputtered with $3 \mathrm{He}^{+}$ions at $1 \mathrm{kV}$ during the analysis and the counts $\mathrm{N}(\mathrm{E}) / \mathrm{E}$ at 
different energy ratios $(\mathrm{eV} / \mathrm{Ep})$ for scattered ions were recorded. The pressure in the analysis chamber during LE-ISS measurements was $1 \cdot 10^{-8}$ Torr.

\subsection{Electrochemical Studies}

The electrodes were prepared according to the procedure described in a previous report [36]; they consisted of carbon cloth backings, diffusion and catalytic layers. The catalytic layer was composed of 33 wt.\% Nafion ionomer (1100 g/eq.) and 67 wt.\% catalyst with Pt loading of $0.3 \mathrm{mg} \mathrm{cm}^{-2}$. MEAs were formed by a hot-pressing procedure and subsequently installed in a fuel cell test fixture. A Nafion 115 membrane $(\sim 100 \mu)$ was preferred to thinner PFSA membranes in order to reduce the effect of $\mathrm{H}_{2}$ cross-over which may affect a rigorous in-situ determination of the mass activity at $0.9 \mathrm{~V}$ RHE.

In the MEAs, the anode was maintained constant $(50 \% \mathrm{Pt} / \mathrm{KB})$ whereas the cathode was varied by using the catalysts described above.

The cell test fixture was connected to a fuel cell test station including an Agilent HP6060B electronic load for polarization experiments, a digital memory oscilloscope and an AUTOLAB Metrohm potentiostat/galvanostat equipped with a 20A current booster for electrochemical diagnostics. The humidifiers temperature was varied with respect to the cell temperature to change the relative humidity (R.H.). The cell temperature was measured by a thermocouple embedded in the cathodic graphite plate, close to the MEA.

Steady-state galvanostatic polarization experiments in PEMFC were performed in the presence of $\mathrm{H}_{2}-\mathrm{O}_{2}$ in a $5 \mathrm{~cm}^{2}$ single cell at various temperature, R.H. and pressure conditions. Cyclic voltammetry (CV) studies were carried out at $80{ }^{\circ} \mathrm{C}$ to determine the ECSA. In this experiment, hydrogen was fed to the anode that operated as both counter and reference electrode, whereas, nitrogen was fed to the working electrode. The sweep rate was $100 \mathrm{mVs}^{-1}$. The electrochemical active surface area was determined by integration of $\mathrm{CV}$ profile in the hydrogen adsorption region after correction for double layer capacitance [17]. An accelerated degradation test (ADT) for the catalysts was carried out in 
PEMFC, at relevant temperature and R.H. conditions. This consisted of $10^{4}$ step cycles between a cell voltage of $0.6 \mathrm{~V}$ and $0.9 \mathrm{~V}$ in the presence of $\mathrm{H}_{2}$ feed at the anode and $\mathrm{O}_{2}$ feed a the cathode. This procedure simulates the practical (cycled) operation of a fuel cell. The potential cycling occurs between two limits represented by a cell potential close to the open circuit voltage OCV $(0.9 \mathrm{~V})$ and the designed operational point of a practical PEMFC $(0.6 \mathrm{~V})$. This is also the potential region where the Pt cathode is less stable. At higher potentials, the occurrence of a Pt-oxide layer stabilizes Pt nanoparticles against dissolution and sintering.

After electrochemical testing, the cathode layers were detached from the membrane and characterized ex-situ by physico-chemical analyses to evaluate Pt sintering and dissolution.

\section{Results and discussion}

\subsection{Physico-chemical studies}

The PtCo catalysts were prepared by using the same procedure excluding the different carbothermal reduction step at $600^{\circ}$ and $800{ }^{\circ} \mathrm{C}$, respectively. X-ray fluorescence indicated an overall $\mathrm{Pt} / \mathrm{Co}$ atomic ratio of about 3 in both catalysts (Table 1) whereas thermal gravimetry confirmed a

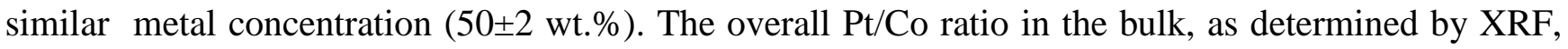
was slightly larger in the sample treated at lower temperature since surface Co atoms are removed with more difficulty after that the alloy has experienced a thermal treatment at very high temperature.

XRD patterns of the $\mathrm{Pt}_{3} \mathrm{Co}_{1} / \mathrm{KB}$ are reported in Figure 1 . The catalysts showed a disordered cubic structure (fcc) for the alloy treated at $600{ }^{\circ} \mathrm{C}$ and single ordered primitive cubic $\left(\mathrm{L} 1_{2}\right)$ phase for the alloy treated at $800{ }^{\circ} \mathrm{C}$. The occurrence of the primitive cubic structure in the sample treated at higher temperatures is evident from the presence of the superlattice reflections i.e. (100), (110) and (210) and a better matching with the JCPDS card (29-0499) for the (Pm $\overline{3} m)$ space group than the JCPDS card (04-0802) related to the $(F m \overline{3} m)$ space group. As well known, the carbon black support is partially crystalline with a hexagonal structure. The main peak (002) is observed at about $25^{\circ}$ two-theta (Fig. 1). 
Mean crystallite size, lattice parameter, atomic ratio in the true alloy or degree of alloying were derived from XRD, particle size from TEM, ECSA from CV. These properties are reported in Table 1. Line broadening analysis of the 220 reflection (Fig. 1) showed a crystallite size of $2.9 \mathrm{~nm}$ for the PtCo treated at $600{ }^{\circ} \mathrm{C}$ and $3.3 \mathrm{~nm}$ for the PtCo catalyst that experienced $800{ }^{\circ} \mathrm{C}$. It seems that the preparation procedure and the carbothermal reduction process mitigate the occurrence of sintering phenomena induced by thermal treatment. In fact, the change in the crystallographic structure with temperature is not accompanied by a relevant change in the crystallite size

For both the PtCo catalysts, a large lattice $\left(\mathrm{A}_{220}\right)$ contraction compared to a $\mathrm{Pt} / \mathrm{C}$ catalyst $\left(\mathrm{A}_{220}=0.392\right)$ corresponding to a high degree of alloying was observed (Table 1$)$. The Co atomic content in the alloy, as determined by XRD, was about $24 \%$ and $29 \%$ in the PtCo samples with disordered and ordered structure, respectively. This was close to the nominal content (25\%). A proper alloying extent is considered a pre-requisite to enhance the catalytic activity [37]. By comparing the atomic $\mathrm{Pt} / \mathrm{Co}$ ratios obtained from $\mathrm{XRD}$ and $\mathrm{XRF}$, slight differences are observed due to the fact that surface Co atoms are slightly more alloyed to Pt in one case (8T) and thus they are leached with more difficulty.

TEM analysis (Fig. 2) showed a good dispersion for both catalysts. The sample treated at high temperature showed the occurrence of a few large particles (up to $10 \mathrm{~nm}$ ) whereas most of the particles were of proper size $(\sim 4 \mathrm{~nm})$. The mean particle size from TEM was similar to the crystallite size determined by XRD in the low temperature treated sample; whereas some deviation was observed for the sample treated at high temperature whose mean particle size was $4.2 \mathrm{~nm}$ (Table 1).

XRD and TEM analysis clearly show that the different thermal treatments cause structural and morphological modifications in the PtCo catalysts which may result in different electro-catalytic properties. 
The surface properties of the catalysts were studied by both XPS and LE-ISS. The survey XPspectra are shown in Figure 3. The analytical peaks related to $4 \mathrm{f}$ orbitals for $\mathrm{Pt}$ and $2 \mathrm{p}$ for Co are indicated. A slight difference in the relative atomic ratio on the surface is derived from XPS (depth analysis $\sim 2 \mathrm{~nm}$ ); an enrichment of Pt atoms on the surface for both catalyst is observed; the surface $\mathrm{Pt} / \mathrm{Co}$ atomic ratio from XPS is about 5:1 for the $6 \mathrm{~T}$ and 4:1 for the $8 \mathrm{~T}$ formulations; after extensive $\mathrm{Ar}^{+}(5 \mathrm{kV})$ sputter treatment, the surface composition approaches the nominal one 3:1 in both cases (not shown). The Pt segregation appears as the direct consequence of both thermal treatment and leaching procedure [38].

An analysis of Pt 4f and Co 2p high resolution spectra (Fig. 4) showed a large prevalence of metallic Pt as confirmed by the occurrence of the $\mathrm{Pt} 4 \mathrm{f}_{7 / 2}$ peak at about $71 \mathrm{eV}$. The Co $2 \mathrm{p}_{3 / 2}$ peak is slightly shifted to lower B.E. for the sample treated at $800{ }^{\circ} \mathrm{C}(778.7 \mathrm{eV})$ with respect to the one treated at $600{ }^{\circ} \mathrm{C}(779 \mathrm{eV})$. This confirms the occurrence of a slightly higher degree of alloying in the sample treated at high temperature [39].

A typical XPS analysis involves a depth of 2-3 nm; but, it appears that in the presence of porous supported catalysts the range is even smaller (as comparison with XRF results); however, the analysis depth can not reduce to the level of the outermost atomic layer. To get direct information about the top-most atomic layer only (which should provide the most relevant contribution in governing the electrochemical behaviour at the catalyst-electrolyte interface), LEISS analysis (Fig. 5) was carried out by using $3 \mathrm{He}^{+}$ions at $1 \mathrm{kV}$. It was possible to observe the occurrence of $\mathrm{C}\left(\mathrm{I} / \mathrm{I}_{0}=0.38 \mathrm{eV} / \mathrm{Ep}\right)$ and $\mathrm{O}$ $\left(\mathrm{I} / \mathrm{I}_{0}=0.48 \mathrm{eV} / \mathrm{Ep}\right)$ elements due to the oxygenated surface functional groups on carbon [40,41]. Whereas the $\mathrm{Pt}\left(\mathrm{I} / \mathrm{I}_{0}=0.94 \mathrm{eV} / \mathrm{Ep}\right)$ peak was significantly larger than $\mathrm{Co}\left(\mathrm{I} / \mathrm{I}_{0}=0.82 \mathrm{eV} / \mathrm{Ep}\right)$ atoms confirming the Pt segregation on the surface [29] for both catalysts. The atomic Pt:Co ratio in the outermost atomic layer as determined from LE-ISS was 15:1 for the sample treated at $600{ }^{\circ} \mathrm{C}$ and 7.5:1 for the sample treated at $800{ }^{\circ} \mathrm{C}$, both subjected to the same leaching treatment after the thermal 
treatment. Such difference is ascribed to the enhanced stability of surface Co atoms in the 8T sample due to a higher degree of alloying. These are removed with more difficulty from the surface with respect to the $6 \mathrm{~T}$ sample.

Since some small evidence of Co signal was observed for the top surface layer in both samples, these could not be treated as a pure skin layer. However, the surface segregation of Pt is clearly assessed by XPS and especially by LE-ISS and, being this Pt enrichment mainly caused by the preleaching [29], the surface structure may be assumed similar to a skeleton layer in both samples $[14,15]$. Ideal pure Pt skin layer properties, sometime observed for extended (bulk) Pt alloys, do not appear easily achievable for practical fuel cell catalysts.

It is derived from XPS and LE-ISS analyses that the different thermal treatment causes slight changes in terms of surface characterisics and electronic properties of the PtCo catalysts. The increase of the temperature should cause an increase of Pt segregation on the surface as observed for extend Pt-alloys. However, the alloy strength also increases with temperature and it becomes more difficult to leach Co atoms from the outermost surface layers. These effects compensate each other. It is important to remember that the leaching treatment in the present procedure is subsequent to the carbothermal reduction. A leaching treatment applied before carbothermal reduction to our amorphous PtOx precursor impregnated with Co may remove most of the electropositive transition metal before this enters into the Pt structure.

\section{2 PEMFC studies}

Electrocatalytic activity, performance and stability characteristics for these catalysts were investigated in relation to the oxygen reduction reaction that is the limiting step of the overall process occurring in PEMFCs. The results were obtained in a Polymer Electrolyte Membrane (PEM) single cell fed with $\mathrm{H}_{2}$ and $\mathrm{O}_{2}$. The reference membrane used in these experiments was Nafion 115. Since, Nafion-type membranes easily dehydrate above $90{ }^{\circ} \mathrm{C}$, it was necessary to raise the pressure up to 3 
bars abs in high temperature experiments to retain a fraction of liquid water inside the MEA. The aim was to compare the behaviour of the catalysts in a wide range of temperatures including those aimed for automotive applications.

The ECSA of these catalysts used as cathodes in PEMFC was investigated by using conventional cyclic voltammetry (Fig. 6). The values determined by CV in the hydrogen adsorption region (Fig. 6) are reported in Table 1 . The ECSA was around $49 \mathrm{~m}^{2} / \mathrm{g}$ for the catalyst treated at $800{ }^{\circ} \mathrm{C}$ and slightly lower for the catalyst treated at lower temperature. Although the difference is not significant, this result seems to be opposite with respect to what envisaged from the particle size and morphology characteristics. However, it should be considered that it may derive from a lower metal-support interaction [40-42] for the sample treated at high temperature thus resulting in a larger availability of Pt sites.

An analysis of the $\mathrm{CV}$ profiles (Fig. 6) shows that the onset of the $\mathrm{Pt}-\mathrm{OH}$ layer formation occurs at about the same potential for both catalysts whereas the coverage of oxygen species on Pt is slightly larger for the sample treated at lower temperature despite its slightly lower surface area, but curiously the charge associated with Pt-oxide reduction seems to be slightly lower in the sample treated at lower temperature and the peak related to the Pt-oxide reduction is more shifted towards higher potentials in the 6T catalyst. From these evidences, one may speculate that the binding energy of oxygenated species is lower in the sample treated at lower temperature being their displacement peak potential (Pt-oxide reduction) more shifted towards the reversible potential. At the same time, it is curious how more labile adsorbed species can reach a larger coverage in the forward sweep. Usually, a shift of the Ptoxide reduction towards higher potentials is assumed as an increase of intrinsic activity as it is often associated with an increase of specific activity for ORR [17]; however, DFT studies have shown that a direct correlation between the coverage of oxygenated species on Pt and the intrinsic catalytic activity is not straightforward [43]. 
The PEMFC polarization curves at $80{ }^{\circ} \mathrm{C}$ and full humidification (Fig. 7a) show similar performance for the two PtCo catalysts under these conditions. IR-drop corrected Tafel curves with the current normalised with respect the Pt loading are reported in the same figure (Fig. 7b) and provide an indication of the electrocatalytic activity in the activation controlled region. As envisaged from the polarization curves, also the Tafel plots show similar electrocatalytic activity. The Tafel slope of 72 $\mathrm{mV} / \mathrm{dec}$ is that expected from a Temkin adsorption condition for the coverage of oxygenated species [44]. At higher temperature $\left(100-110{ }^{\circ} \mathrm{C}\right)$ and full humidification, the disordered fcc structure based PtCo catalyst shows lower electrocatalytic activity in the activation region resulting in lower mass activity at the same potential but larger limiting current density resulting in better peak power density (Fig. 8). Such behaviour may be attributed to the better dispersion and the smaller particle size observed for the disordered fcc structure-based PtCo with respect to the high temperature treated sample. The morphology characteristics of the sample treated at $600{ }^{\circ} \mathrm{C}$ appear to produce lower mass transport constraints.

The different characteristics of the two catalysts are exacerbated by operation under low relative humidity (33\% R.H.). In the presence of low relative humidity (Fig. 9) the disordered fcc structure catalyst is better performing at low temperature but only at high current densities; at high temperature the ordered catalyst is performing better both at low and high current densities achieving a mass activity of $0.32 \mathrm{~A} / \mathrm{mg}$ at $0.9 \mathrm{~V}, 110{ }^{\circ} \mathrm{C}, 33 \%$ R.H. , 3 bar abs. $\mathrm{O}_{2}$ (Fig. 9).

The Tafel slope slightly increases with the temperature under full humidification as expected; interestingly, it also increases with the decrease of relative humidity. The proton availability related to the water content has of course an effect on the electro-kinetic parameters. A significant reduction of relative humidity causes a decrease of proton availability and a consequent increase of the activation barrier for the ORR. 
This effect is clearly observed in Fig. 10 where the influence of temperature on the polarization curves and Tafel plots at low R.H. (33\%) is reported in the range $80^{\circ} \mathrm{C}-130^{\circ} \mathrm{C}$. Despite, the high absolute pressure, 3 bar abs, it is clearly observed that there is a dramatic decrease of performance and a change in the Tafel curve at $130{ }^{\circ} \mathrm{C}$; these aspects may be associated to both membrane and ionomer dry-out resulting in a lower availability of protons at the catalyst-ionomer electrolyte interface since the Tafel plots are IR-corrected.

At high pressure, there is not much change in catalytic activity with temperature in the range $80^{\circ}-110$ ${ }^{\circ} \mathrm{C}$ (Fig. 10); a large difference is observed for the limiting current that increases with temperature in the useful range as evidence of lower mass transport control.

In Table 2, mass activity and power densities are compared at two relevant temperatures and R.H. conditions, one simulating conventional low temperature operation the other related to the automotive application (high temperature and low R.H.). From this analysis, it appears that the catalyst with the ordered cubic primitive structure allows to achieve a significant performance and catalytic activity enhancement under the conditions aimed for automotive operation. Of course, for automotive operation, it is also desirable to avoid high pressure conditions. It was not possible to run experiments at high temperature and low pressure with Nafion due to the membrane dehydration. At conventional temperature, $80^{\circ} \mathrm{C}$, (Fig. 11), there is a clear increase of catalytic activity in the activation region from 1.5 to 2 bars $(40 \mathrm{mV})$ for the ordered catalyst. This is somewhat expected since the oxygen reduction process is a first order reaction but not much increase is recorded from 2 to 3 bar rel. It appears not straightforward to describe the effective catalytic behaviour under practical operation with a conventional adsorption isotherm and some saturation effects for the coverage of oxygen reaction intermediates may already occur at low pressures. However, the pressure has generally a significant effect on the limiting current since this parameter is essentially controlled by mass transport. 
Accelerated degradation tests i.e. $10^{4}$ step cycles (steps 0.6-0.9 V, $\mathrm{H}_{2}-\mathrm{O}_{2}$ ) were carried out for both catalysts under conditions resembling automotive operation i.e. $110{ }^{\circ} \mathrm{C}, 33 \%$ R.H. After the degradation test at $110{ }^{\circ} \mathrm{C}$ and $33 \%$ R.H., polarization curves were carried out at both $110{ }^{\circ} \mathrm{C}, 33 \%$ R.H (Fig. 12a) and $80{ }^{\circ} \mathrm{C}, 100 \%$ R.H (Fig. 12b). At high temperature, clear humidification constraints for the membrane appeared at low current density after $10^{4}$ cycles (Fig. 12a). Both MEAs appeared to take benefit of internal humidification at high currents. In the high current region where self humidification reduces the effects related to the membrane degradation both catalysts showed moderate performance decay (Fig. 12a). When the polarization curves were carried out at $80{ }^{\circ} \mathrm{C}$ and $100 \%$ R.H. i.e. in a condition where the water content does not produce any limiting effect, a significant decay was recorded for the $600{ }^{\circ} \mathrm{C}$-treated catalyst, whereas a very small decay was recorded for the $800{ }^{\circ} \mathrm{C}$ treated catalyst (Fig. 12b). The increased water content caused probably dissolution into the ionomer and membrane of the Co ions leached out from the 6T catalyst by effect of the accelerated test with consequent poisoning of the electrolyte and increase of ohmic drop and activation constraints (Fig.12b).

A comparison of TEM micrographs (Fig. 13) for the raw catalysts and after the accelerated degradation test (catalysts were scraped from the electrodes) showed that in the case of the 6T sample there were evident regions where dissolution and re-precipitation on larger particles (Ostwald ripening) occurred; a moderate increase of the mean particle size was recorded in this sample; whereas in the case of the $800{ }^{\circ} \mathrm{C}$-treated catalyst no significant morphological changes were observed and the mean particle size essentially remained the same as before the ADT (Fig. 13).

A comparison of the CV profiles before and after the degradation process in the two samples is provided in Fig. 14a-c. No significant changes were observed in the hydrogen adsorption branch for the disordered fcc structure catalyst (6T), whereas an increase of the coverage of oxygenated species was observed above $0.8 \mathrm{~V}$ RHE (Fig. 14b). The Pt-oxide reduction peak was shifted to higher potentials 
indicating an increase of intrinsic (specific) activity probably related to the increase of the particle size in the $6 \mathrm{~T}$ sample $[5,17]$. The $\mathrm{CV}$ profile of the high temperature treated catalyst showed a slight increase in the hydrogen adsorption-desorption branch (Fig. 14a). As speculative hypothesis, this may be probably related to a surface corrugation of the nanoparticles as a result of the electrochemical procedure. It is clearly envisaged in the $8 \mathrm{~T}$ sample an increase of $\mathrm{OH}$ species coverage at high potentials and the corresponding increase of current in the cathodic Pt-O reduction peak (Fig. 14a). This is only moderately shifted since there was indeed no much change in the mean particle size. In Table 3, it is reported the crystallite size dimension and electrochemical active surface area (ECSA) before and after the accelerated degradation test (ADT).

If we directly compare the CV profile of both catalysts after the ADT (Fig. 14c), we can affirm that the active surface area after the degradation test is higher in the $800{ }^{\circ} \mathrm{C}$-treated catalyst; but, more relevant is the significantly larger coverage of oxidised Pt species in the latter sample. It is assumed that if the alloy nanoparticles are quite stable as in the case of the $8 \mathrm{~T}$ sample (e.g. absence of coalescence and leaching of transition metal), the growth of an oxide layer on the surface may easily occur at intermediate temperatures e.g. $110^{\circ} \mathrm{C}$ and low R.H.; this further stabilizes the catalyst against corrosion. Strasser et. al. investigated the effect of annealing temperature on the electro-catalytic activity of Pt-Co catalysts [45-47]. They have found that based on the compressive Pt-Pt distance of the surface atoms, the d-band structure is weakened for the adsorption energy of reactive intermediates such as $\mathrm{OH}$ species leading to an increase in activity for the ORR [47]. An inhibition of OH adsorption was also considered by He and Mukerjee to explain the high activity of PtCo catalysts [48]. On the other hand, modified Pt-Co- CeOx catalysts showed that an enhanced oxygen supply to the Pt-Co alloy results in improved electrochemical performance for the ORR [49]. All these studies were carried out at low temperatures and there are no detailed reports in the literature concerning with this field for the intermediate $110^{\circ}-130{ }^{\circ} \mathrm{C}$ temperature range. We understand that the occurrence of this oxide layer 
may indeed cause initially a small decrease of performance but the corresponding decay of activity with time appears smaller that that observed for the $6 \mathrm{~T}$ catalyst that is more subjected to dissolution and re-precipitation phenomena.

\section{Conclusion}

The effect of thermal treatment on the structure and surface composition of PtCo electro-catalysts was investigated. The catalysts were pre-leached in acidic solution to get a proper enrichment of Pt on the surface of the nanoparticles as required to enhance performance and stability. The electrocatalysts were investigated for application in PEMFCs operating under various conditions including those aimed for automotive applications i.e. high temperature and low relative humidity. It was observed that the different thermal treatments cause significant structural and morphological modifications in the PtCo catalysts whereas moderate changes occurred in terms of surface composition and electronic properties. The structural and morphology modifications resulted in different electro-catalytic properties especially under operation at high temperature and low relative humidity. Under these conditions which are aimed by the automakers, the catalyst treated at $800{ }^{\circ} \mathrm{C}$ showed the best performance and stability. No significant changes in active surface area and electrocatalytic activity was recorded after 10000 step cycles at high temperature and low R.H. This relevant result is ascribed to the growth of a stable oxide layer on the surface of the surface Pt enriched alloy nanoparticles with primitive cubic ordered structure which protects them from sintering and dissolution. This approach may provide a suitable route to enhance the stability of carbon supported Pt-alloys while maintaining suitable performance for the oxygen reduction process.

\section{Acknowledgement}

The authors acknowledge the financial support of the EU through the QuasiDry Project 256821. "The research leading to these results has received funding from the European Community's Seventh 
Framework Programme (FP7/2010-2013) under the call ENERGY-2010-10.2-1: Future Emerging Technologies for Energy Applications (FET).” 


\section{References}

[1] J.R.C. Salgado, E. Antolini, E.R. Gonzalez, J. Phys. Chem. B 108 (2004) 17767-17774.

[2] H.A. Gasteiger, S.S. Kocha, B. Sompalli, F.T. Wagner, Appl. Catal. B: Environ. 56 (2005) 9-35.

[3] C. Jaffray, G.A. Hards, in: W. Vielstich, A. Lamm, H. Gasteiger (Eds.), Handbook of Fuel Cells Fundamentals, Technology and Applications, vol. 3, Wiley, Chichester, UK, 2003, p. 509 (Chapter 41).

[4] J. Scholta, N. Berg, P. Wilde, L. Jorissen, J. Garche, J. Power Sources 127 (2004) 206-212.

[5] N. Giordano, E. Passalacqua, L. Pino, A.S. Arico,V. Antonucci, M. Vivaldi, K. Kinoshita, Electrochim. Acta 36 (1991) 1979-1984.

[6] O. Antoine, Y. Bultel, R. Durand, J. Electroanal. Chem. 499 (2001) 85-94.

[7] S. Mukerjee, S. Srinivasan, M. P. Soriaga, J. McBreen, J. Electrochem. Soc. 142 (1995) 1409-1422.

[8] R. Loukrakpam et al., J. Phys. Chem. C 115 (2011) 1682-1694.

[9] V. Jalan, E.J. Taylor, J. Electrochem. Soc. 130 (1983) 2299-2302.

[10] B.C. Beard, P.N. Ross, J. Electrochem. Soc. 137 (1990) 3368-3374.

[11] A. Freund, J. Lang, T. Lehman, K.A. Starz, Cat. Today 27 (1996) 279-283.

[12] V. Stamenkovic, T.J. Schmidt, P.N. Ross, N.M. Markovic, J. Phys. Chem. B 106 (2002) 1197011979.

[13] N.M. Markovic, P.N. Ross, Surf. Sci. Rep. 45 (2002) 117-125.

[14] V.R. Stamenkovic, B.S. Mun, M. Arenz, K.J.J. Mayrhofer, C.A. Lucas, G. Wang, P.N. Ross, N.M. Markovic, Nat. Mater. 6 (2007) 241-247.

[15] V. Stamenkovic, B.S. Mun, K.J.J. Mayrhofer, P.N. Ross, N.M. Markovic, J. Rossmeisl, J. Greeley, J.K. Norskov, Angew. Chem., Int. Ed. 45 (2006) 2897-2901.

[16] T. Toda, H. Igarashi, M. Watanabe, J. Electroanal. Chem. 460 (1999) 258-262. 
[17] A.S. Aricò, A. Stassi,E. Modica, R. Ornelas, I. Gatto, E. Passalacqua, V. Antonucci, J. Power Sources 178 (2008) 525-536.

[18] R.L. Borup, J.R. Davey, F.H. Garzon, D.L. Wood, M.A. Inbody, J. Power Sources 163 (2006) 7681.

[19] H.R. Colon-Mercado, B.N. Popov, J. Power Sources 155 (2006) 253-263.

[20] M. Cai, M.S. Ruthkosky, B. Merzougui, S. Swathirajan, M.P. Balogh, J. Power Sources 160 (2006) 977-986.

[21] S.C. Ball, S.L. Hudson, D. Thompsett, B. Theobald, J. Power Sources 171 (2007) 18-25.

[22] P. Yu, M. Pemberton, P. Plasse, J. Power Sources 144 (2005) 11-20.

[23] X. Wang, W. Li, Z. Chen, M. Waje, Y. Yan, J. Power Sources 158 (2006) 154-159.

[24] S. Chen, W. Sheng,N. Yabuuchi, P.J. Ferreira, L.F. Allard,Y. Shao-Horn, J. Phys. Chem. C 113 (2009) 1109-1125.

[25] K. Jayasayee,T.D. Van Anh, T. Verhoeven, S. Celebi, F.A. De Bruijn, J. Phys. Chem. C 113 (2009) 20371-20380.

[26] A. Stassi, E. Modica, V. Antonucci, A.S. Aricò, Fuel Cells 9 (2009) 201-208.

[27] F. Tian, A.B. Anderson, J. Phys. Chem. C 112 (2008) 18566-18571.

[28] V.R. Stamenkovic, B.S. Mun, K.J.J. Mayrhofer, P.N. Ross, N.M. Markovic, J. Am. Chem. Soc. 128 (2006) 8813-8819.

[29] A. S. Aricò, A. Stassi, I. Gatto, G. Monforte, E. Passalacqua, V. Antonucci, J. Phys. Chem. C 114 (2010) 15823-15836.

[30] J. Peron, Y. Nedellec, D. J. Jones, J. Rozière, J. Power Sources 185 (2008) 1209-1217.

[31] A. Stassi, I. Gatto, E. Passalacqua, V. Antonucci, A. S. Aricò, L. Merlo, C. Oldani, E. Pagano, J. Power Sources 196 (2011) 8925-8930. 
[32] L. J. Bonville, H. Russell Kunz, Y. Song, A. Mientek, M. Williams, A.Ching, J. M. Fenton, J. Power Sources 144 (2005) 107-112.

[33] A. S. Aricò, A. Di Blasi, G. Brunaccini, F. Sergi, G. Dispenza, L. Andaloro, M. Ferraro, V. Antonucci, P. Asher, S. Buche, D. Fongalland, G. A. Hards, J. D. B. Sharman, A. Bayer, G. Heinz， N. Zandonà, R. Zuber, M. Gebert, M. Corasaniti, A. Ghielmi, D. J. Jones, Fuel Cells 10 (2010) 1013-1023.

[34] A.S. Aricò, V. Baglio, A. Di Blasi, E. Modica, P.L. Antonucci, V. Antonucci, J. Electroanal. Chem. 557 (2003) 167-176.

[35] J.F. Moulder, W.F. Stickle, P.E. Sobol, K.D. Bomben, in: Handbook of X-ray Photoelectron Spectroscopy, Physical Electronics, Inc, Eden Prairie, MN, 1995.

[36] A.S. Aricò, A.K. Shukla, K.M. El-Khatib, P. Cretì, V. Antonucci, J. Appl. Electrochem. 29 (1999) 671-676.

[37] B.J. Hwang, S.M.S. Kumar, C.-H. Chen, Monalisa, M.-Y. Cheng, D.-G. Liu, J.-F. Lee, J. Phys. Chem. C 111 (2007) 15267-15276.

[38] H.T. Duong, M.A. Rigsby, W.-P. Zhou, A. Wieckowski, J. Phys. Chem. C 111 (2007) 1346013465.

[39] A.S. ， A.K. Shukla, H. Kim, S. Park, M. Min, V. Antonucci, Appl. Surf. Sci. 172 (2001) 3340.

[40] A.S. Aricò, V. Antonucci, M. Minutoli, N. Giordano, Carbon 27 (1989) 337-347.

[41] A.S. Aricò, V. Antonucci, L. Pino, P.L. Antonucci, N. Giordano, Carbon 28 (1990) 599-609.

[42] A.S. Aricò, P.L. Antonucci, V. Antonucci, in: A. Wieckowski, E.R. Savinova, C.G. Vayenas (Eds.), Catalysis and Electrocatalysis at Nanoparticle Surfaces, Marcel Dekker, Inc., New York, 2003.

[43] J. Rossmeisl, G.S. Karlberg, T. Jaramillo, J.K. Norskov, Faraday Discuss. 140 (2008) 337-347. 
[44] A.S. Aricò, V. Antonucci, V. Alderucci, E. Modica, N. Giordano, J. Applied Electrochem., 23 (1993) 1107-1116.

[45] S. Koh, M.F. Toney, P. Strasser, Electrochim.Acta, 52 (2007) 2765-2774.

[46] M., Oezaslan, P. Strasser, J. of Power Sources, 196 (2011) 5240-5249.

[47] P. Strasser, S. Koh, T. Anniyev, J. Greeley, K. More, C. Yu, Z. Liu, S. Kaya, D. Nordlund, H. Ogasawara, M.F. Toney, A. Nilsson, Nat. Chem., 2 (2010) 454-460.

[48] Q He, S. Mukerjee, Electrochim. Acta, 55 (2010) 1709-1719.

[49] K.H. Lee, K. Kwon, V. Roev, D.Y. Yoo, H. Chang, D. Seung, J. of Power Sources, 185 (2008) $871-875$ 


\section{Table 1.}

Physico-chemical properties of prepared catalysts

\begin{tabular}{|c|c|c|c|c|c|c|c|c|}
\hline Catalysts & Treatment & $\begin{array}{l}\text { Overall } \\
\text { Pt/Co } \\
\text { at. ratio } \\
\text { (XRF) }\end{array}$ & Structure & $\begin{array}{l}\mathrm{A}_{220} \\
\mathrm{~nm}\end{array}$ & $\begin{array}{l}\text { at. \% Co } \\
\text { in the } \\
\text { alloy } \\
\text { (XRD) }\end{array}$ & $\begin{array}{c}\text { Crystallite } \\
\text { size } \\
\text { (XRD) } \\
\text { nm }\end{array}$ & $\begin{array}{c}\text { Particle } \\
\text { size } \\
\text { (TEM) } \\
\text { nm }\end{array}$ & $\begin{array}{l}\text { ECSA } \\
(\mathrm{CV}) \\
\mathrm{m}^{2} / \mathrm{g}\end{array}$ \\
\hline $\begin{array}{l}50 \% \mathrm{PtCo} / \mathrm{C} \\
6 \mathrm{~T}\end{array}$ & $\begin{array}{c}600{ }^{\circ} \mathrm{C} \\
\text { pre- } \\
\text { leached }\end{array}$ & 3.4 & $\begin{array}{c}\text { Face } \\
\text { centered } \\
\text { cubic } \\
\text { disordered }\end{array}$ & 0.383 & 23.8 & 2.9 & 2.9 & 47.6 \\
\hline $\begin{array}{l}50 \% \mathrm{PtCo} / \mathrm{C} \\
8 \mathrm{~T}\end{array}$ & $\begin{array}{c}800{ }^{\circ} \mathrm{C} \\
\text { pre- } \\
\text { leached }\end{array}$ & 3.0 & $\begin{array}{c}\text { Primitive } \\
\text { cubic } \\
\left(\mathrm{L1}_{2}\right) \\
\text { ordered }\end{array}$ & 0.381 & 29.4 & 3.3 & 4.2 & 49.2 \\
\hline
\end{tabular}


Table 2

Mass activity and power densities at conventional and automotive conditions.

\begin{tabular}{|c|c|c|c|c|c|c|c|}
\hline Catalysts & $\begin{array}{c}\mathrm{T} \\
\left({ }^{\circ} \mathrm{C}\right)\end{array}$ & $\begin{array}{c}\mathrm{P} \\
\text { (bar abs) }\end{array}$ & $\begin{array}{l}\text { R.H. } \\
(\%)\end{array}$ & $\begin{array}{c}\text { Mass Activity } \\
\text { @ } 0.9 \mathrm{~V} \\
(\mathrm{~mA} / \mathrm{mg})\end{array}$ & $\begin{array}{c}\text { Tafel } \\
\text { Slope } \\
\text { (mV/dec) }\end{array}$ & $\begin{array}{l}\text { Power Density } \\
\qquad 0.65 \mathrm{~V} \\
\left(\mathrm{~mW} / \mathrm{cm}^{2}\right)\end{array}$ & $\begin{array}{c}\text { Maximum } \\
\text { Power } \\
\text { Density } \\
\left(\mathrm{mW} / \mathrm{cm}^{2}\right)\end{array}$ \\
\hline $\begin{array}{l}50 \% \mathrm{PtCo} / \mathrm{C} \\
6 \mathrm{~T} \text { (disordered) }\end{array}$ & 80 & 3.0 & 100 & 360 & 72 & 690 & 885 \\
\hline $\begin{array}{l}50 \% \mathrm{PtCo} / \mathrm{C} \\
8 \mathrm{~T} \text { (ordered) }\end{array}$ & 80 & 3.0 & 100 & 360 & 72 & 656 & 823 \\
\hline $\begin{array}{l}50 \% \mathrm{PtCo} / \mathrm{C} \\
6 \mathrm{~T} \text { (disordered) }\end{array}$ & 110 & 3.0 & 33 & 185 & 86 & 366 & 531 \\
\hline $\begin{array}{l}50 \% \mathrm{PtCo} / \mathrm{C} \\
8 \mathrm{~T} \text { (ordered) }\end{array}$ & 110 & 3.0 & 33 & 320 & 76 & 656 & 847 \\
\hline
\end{tabular}




\section{Table 3}

Crystallite size dimension and ECSA before and after ADTs.

\begin{tabular}{lcccc}
\hline \hline \multirow{2}{*}{ Catalysts } & ECSA & ECSA & Cryst. size & Cryst. size \\
& $\begin{array}{c}\text { After ADT } \\
\left(\mathrm{m}^{2} / \mathrm{g}\right)\end{array}$ & $\begin{array}{c}\text { After ADT } \\
\left(\mathrm{m}^{2} / \mathrm{g}\right)\end{array}$ & $\begin{array}{c}\text { Before ADT } \\
\text { TEM (nm) }\end{array}$ & $\begin{array}{c}\text { After ADT } \\
\text { TEM (nm) }\end{array}$ \\
\hline \hline $50 \% \mathrm{PtCo} / \mathrm{C}$ 6T (disordered) & 46.7 & 45.4 & 3.0 & 4.2 \\
\hline $50 \% \mathrm{PtCo} / \mathrm{C}$ 8T (ordered) & 49.2 & 53.0 & 4.2 & 4.2 \\
\hline
\end{tabular}




\section{Captions to Figures}

Fig. 1 XRD patterns of Ketjenblack carbon-supported 50\% PtCo/C 8T (A) and 50\% $\mathrm{PtCo} / \mathrm{C} 6 \mathrm{~T}$ (B) electrocatalysts.

Fig. 2 Transmission electron micrographs of Ketjenblack carbon-supported electrocatalysts: a) $50 \% \mathrm{PtCo} / \mathrm{C} 8 \mathrm{~T}$; b) $50 \% \mathrm{PtCo} / \mathrm{C} 6 \mathrm{~T}$.

Fig. 3 Comparison of survey spectra for Ketjenblack carbon-supported $50 \% \mathrm{PtCo} / \mathrm{C} 8 \mathrm{~T}$ and $50 \% \mathrm{PtCo} / \mathrm{C}$ $6 \mathrm{~T}$ electrocatalysts.

Fig. 4 X-ray photoelectron spectra of carbon-supported $50 \% \mathrm{PtCo} / \mathrm{C} 8 \mathrm{~T}$ and $50 \% \mathrm{PtCo} / \mathrm{C} 6 \mathrm{~T}$ electrocatalysts; a) Pt 4f; b) Co 2p.

Fig. 5 Low-energy ion scattering spectroscopy $\left(3 \mathrm{He}^{+}, 1 \mathrm{kV}\right)$ of carbon-supported $50 \% \mathrm{PtCo} / \mathrm{C} 8 \mathrm{~T}$ and $50 \% \mathrm{PtCo} / \mathrm{C} 6 \mathrm{~T}$ electrocatalysts.

Fig. 6 Comparison of the $\mathrm{CV}$ profiles $\left(100 \mathrm{mV} \mathrm{s}^{-1}\right)$ for the carbon-supported $50 \% \mathrm{PtCo} / \mathrm{C} 8 \mathrm{~T}$ (dashedline) and 50\% $\mathrm{PtCo} / \mathrm{C} 6 \mathrm{~T}$ (solid-line) electrocatalysts.

Fig. 7 a) Comparison of the polarization behavior for the carbon-supported $50 \% \mathrm{PtCo} / \mathrm{C} 8 \mathrm{~T}$ and $50 \% \mathrm{PtCo} / \mathrm{C}$ 6T electrocatalysts at $80{ }^{\circ} \mathrm{C}$ and $100 \% \mathrm{RH}$; b) Comparison of the Tafel plots in the activation controlled region for the carbon-supported $50 \% \mathrm{PtCo} / \mathrm{C} \quad 8 \mathrm{~T}$ and $50 \% \mathrm{PtCo} / \mathrm{C} 6 \mathrm{~T}$ electrocatalysts at $80^{\circ} \mathrm{C}$ and $100 \% \mathrm{RH}$. 
Fig. 8 a-b) Comparison of the polarization behavior for the carbon-supported $50 \% \mathrm{PtCo} / \mathrm{C} 8 \mathrm{~T}$ and 50\% PtCo/C 6T electrocatalysts: (a) at $100{ }^{\circ} \mathrm{C}$ and $100 \% \mathrm{RH}$; (b) at $110{ }^{\circ} \mathrm{C}$ and $100 \% \mathrm{RH} . \mathrm{c}-\mathrm{d}$ ) Comparison of the Tafel plots in the activation controlled region for the carbon-supported $50 \% \mathrm{PtCo} / \mathrm{C}$ $8 \mathrm{~T}$ and $50 \% \mathrm{PtCo} / \mathrm{C}$ 6T electrocatalysts: (c) at $100{ }^{\circ} \mathrm{C}$ and $100 \% \mathrm{RH}$; (d) at $110{ }^{\circ} \mathrm{C}$ and $100 \% \mathrm{RH}$.

Fig. 9 a-b) Comparison of the polarization behavior for the carbon-supported 50\% $\mathrm{PtCo} / \mathrm{C} 8 \mathrm{~T}$ and 50\% PtCo/C 6T electrocatalysts: (a) at $80{ }^{\circ} \mathrm{C}$ and $33 \% \mathrm{RH}$; (b) at $110{ }^{\circ} \mathrm{C}$ and $33 \% \mathrm{RH}$. c-d) Comparison of the Tafel plots in the activation controlled region for the carbon-supported $50 \% \mathrm{PtCo} / \mathrm{C} 8 \mathrm{~T}$ and $50 \% \mathrm{PtCo} / \mathrm{C} 6 \mathrm{~T}$ electrocatalysts: (c) at $80{ }^{\circ} \mathrm{C}$ and $33 \% \mathrm{RH}$; (d) at $110{ }^{\circ} \mathrm{C}$ and $33 \% \mathrm{RH}$.

Fig. 10 a) Effect of the temperature on the polarization behavior for the carbon-supported $50 \% \mathrm{PtCo} / \mathrm{C}$ $8 \mathrm{~T}$ electrocatalyst at 33\% RH; b) Effect of the temperature on the Tafel plots for the carbon-supported $50 \% \mathrm{PtCo} / \mathrm{C} 8 \mathrm{~T}$ electrocatalyst at $33 \% \mathrm{RH}$.

Fig. 11 Effect of the pressure on the Tafel plots for the carbon-supported 50\% PtCo/C 8T electrocatalyst at $80{ }^{\circ} \mathrm{C}$ and $100 \% \mathrm{RH}$.

Fig. 12 Comparison of the polarization behavior before and after ADTs for the carbon-supported $50 \% \mathrm{PtCo} / \mathrm{C} 8 \mathrm{~T}$ and $50 \% \mathrm{PtCo} / \mathrm{C} 6 \mathrm{~T}$ electrocatalysts: (a) at $110{ }^{\circ} \mathrm{C}$ and $33 \% \mathrm{RH}$; (b) at $80{ }^{\circ} \mathrm{C}$ and $100 \%$ RH. 
Fig. 13 Transmission electron micrographs at different magnifications of carbon-supported electrocatalysts: a) $50 \% \mathrm{PtCo} / \mathrm{C} 6 \mathrm{~T}$ before $\mathrm{ADT}$; b) $50 \% \mathrm{PtCo} / \mathrm{C} 6 \mathrm{~T}$ after $\mathrm{ADT}$; c) $50 \% \mathrm{PtCo} / \mathrm{C} 8 \mathrm{~T}$ before ADT; d) $50 \% \mathrm{PtCo} / \mathrm{C} 8 \mathrm{~T}$ after ADT.

Fig. 14 Comparison of the $\mathrm{CV}$ profiles $\left(100 \mathrm{mV} \mathrm{s}^{-1}\right)$ before and after ADTs: a) for the carbonsupported 50\% PtCo/C 8T before (solid-line) and after (dashed-line) ADT; b) for the carbon-supported $50 \% \mathrm{PtCo} / \mathrm{C} 6 \mathrm{~T}$ before (solid-line) and after (dashed-line) ADT; c) comparison after ADTs between carbon-supported 50\% PtCo/C $8 \mathrm{~T}$ and $50 \% \mathrm{PtCo} / \mathrm{C} 6 \mathrm{~T}$ electrocatalysts. 


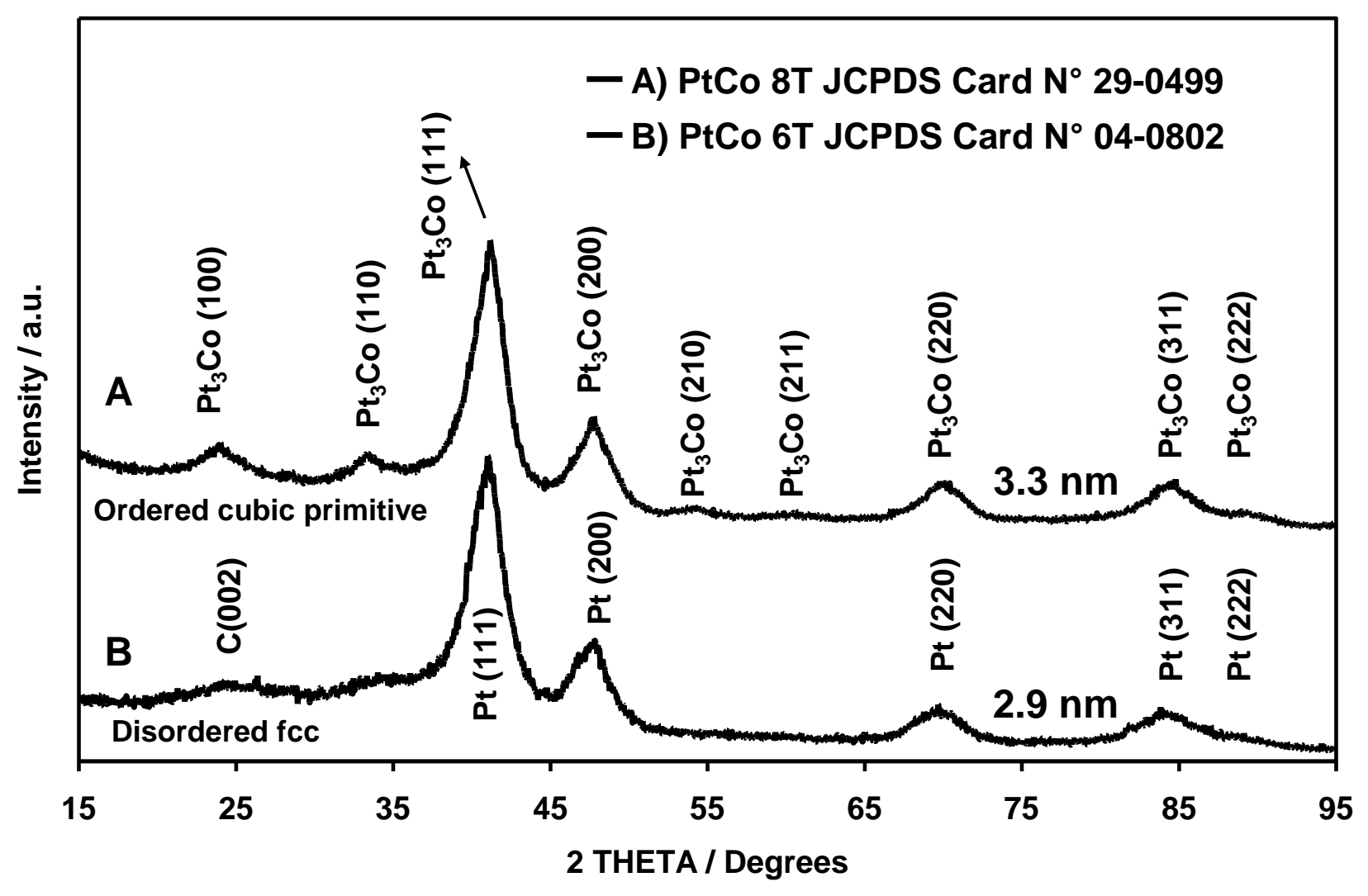

Fig. 1 

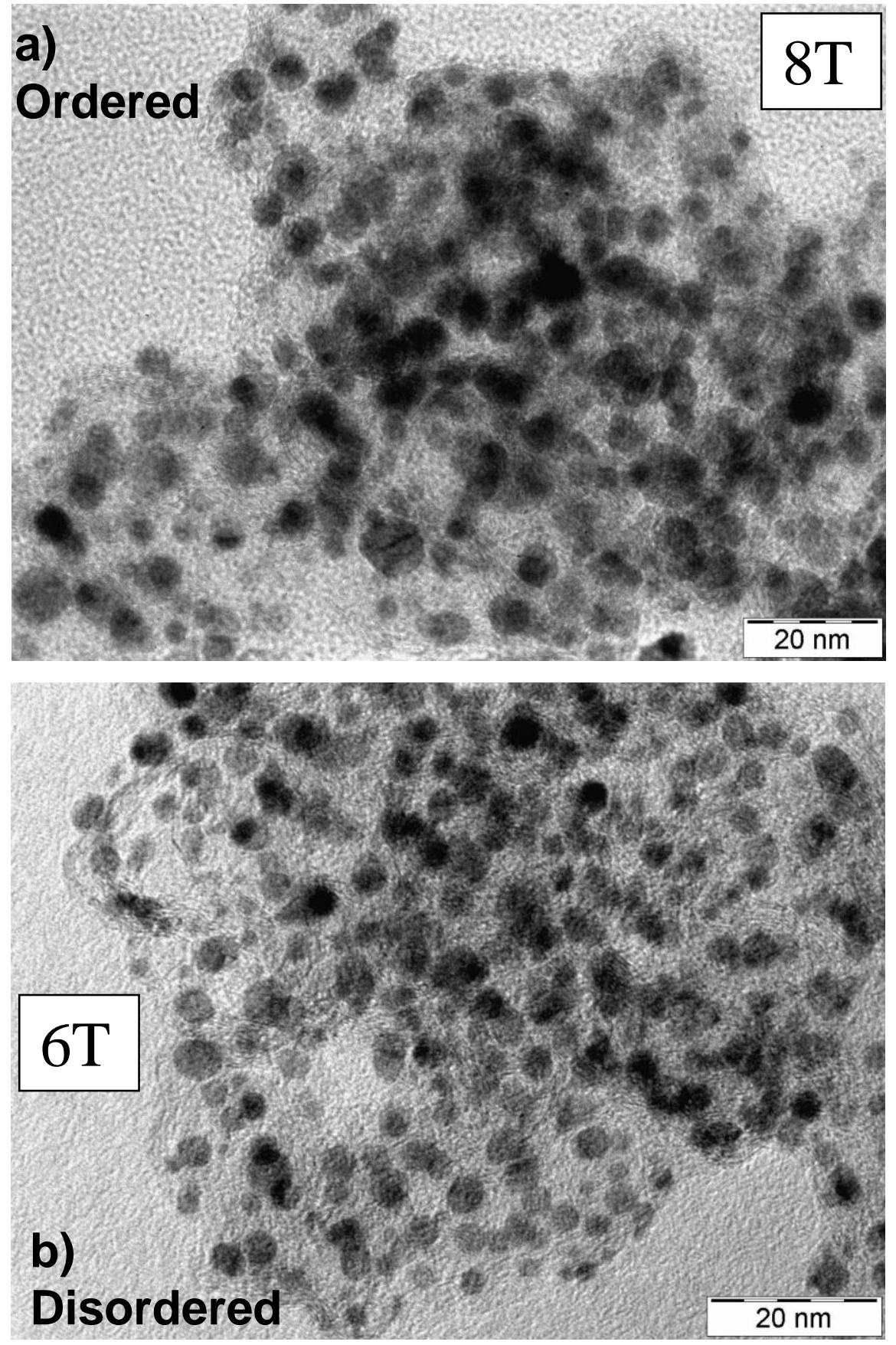

Fig. 2 


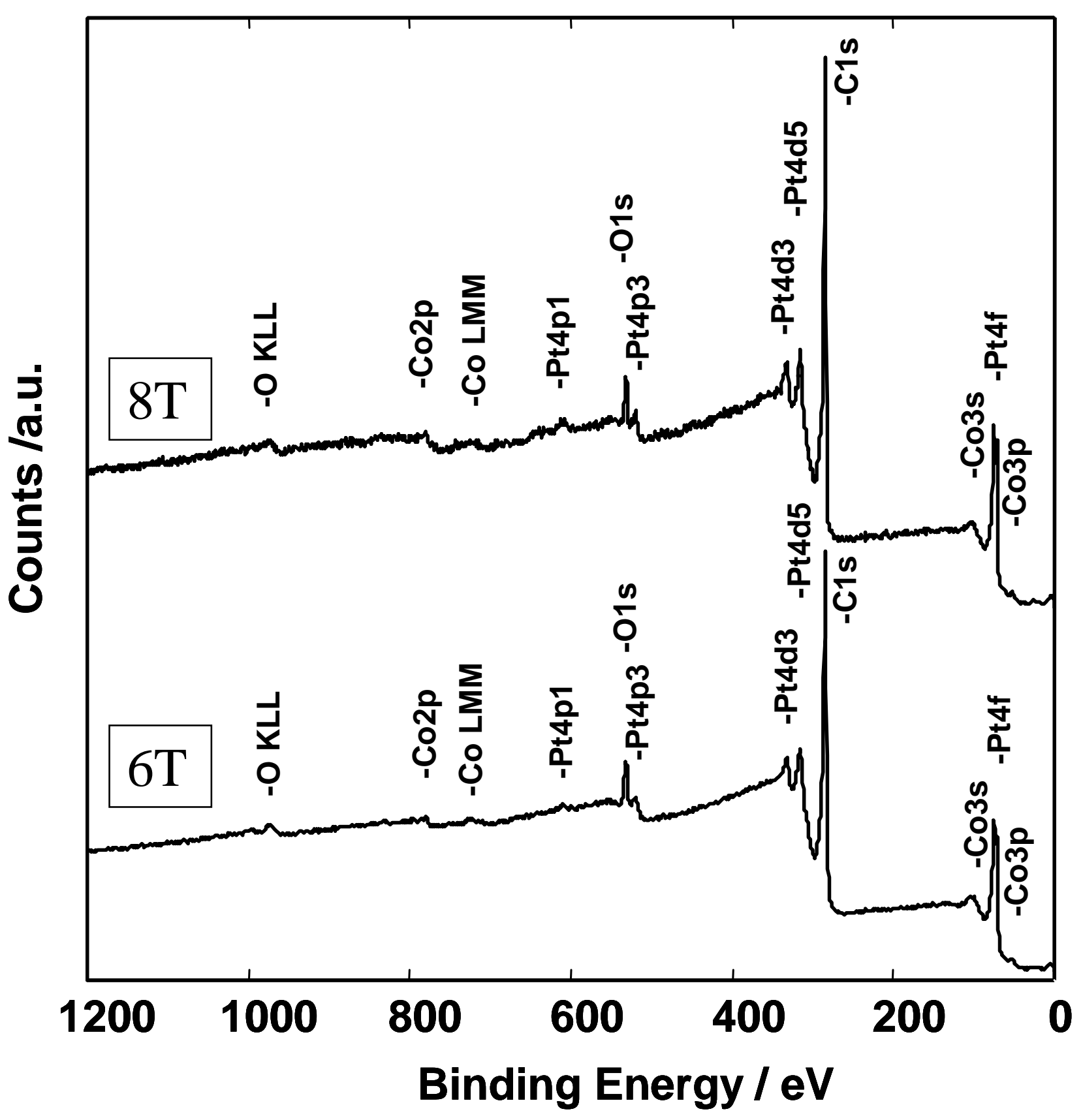

Fig. 3 

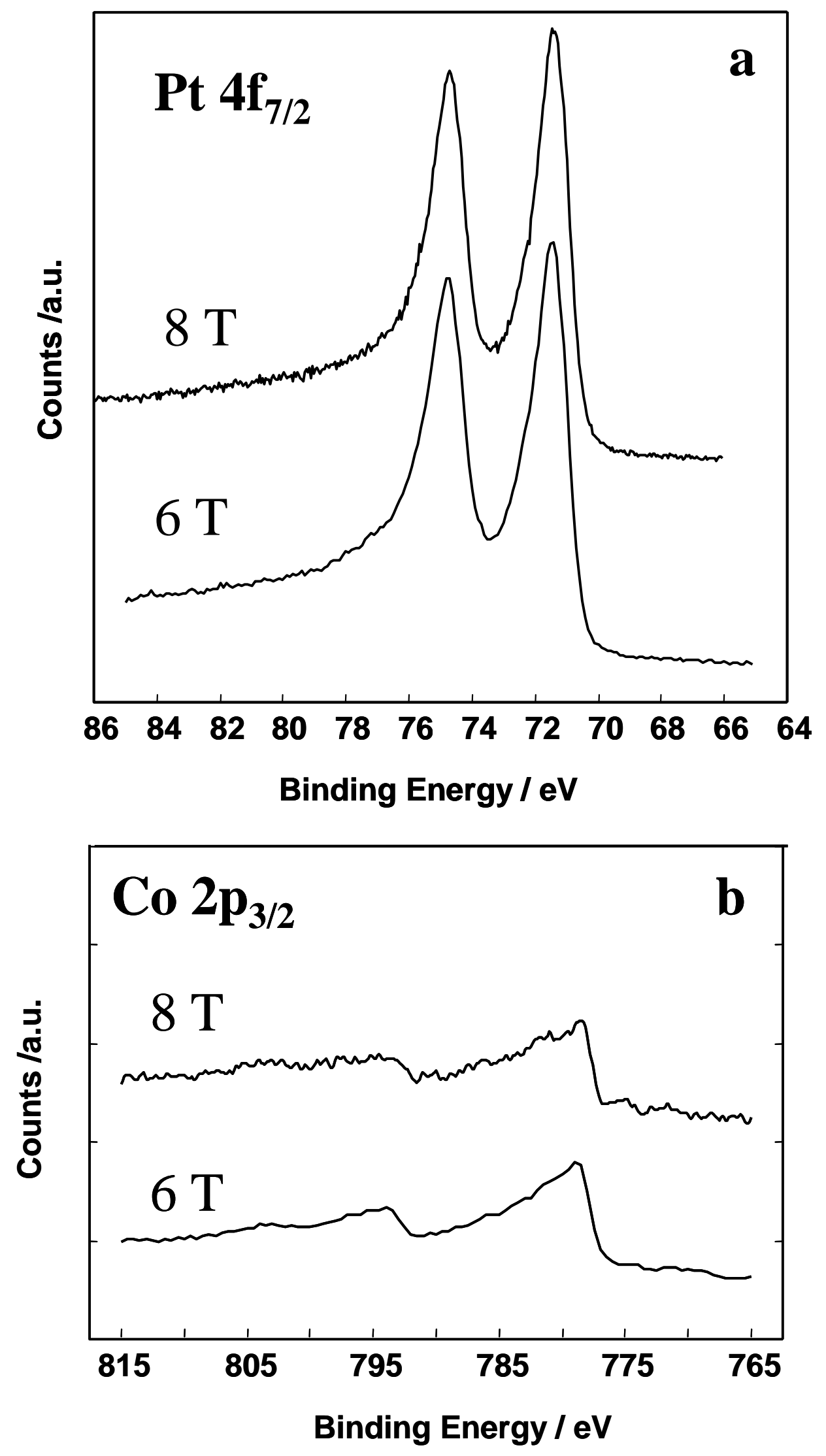

Fig. 4 


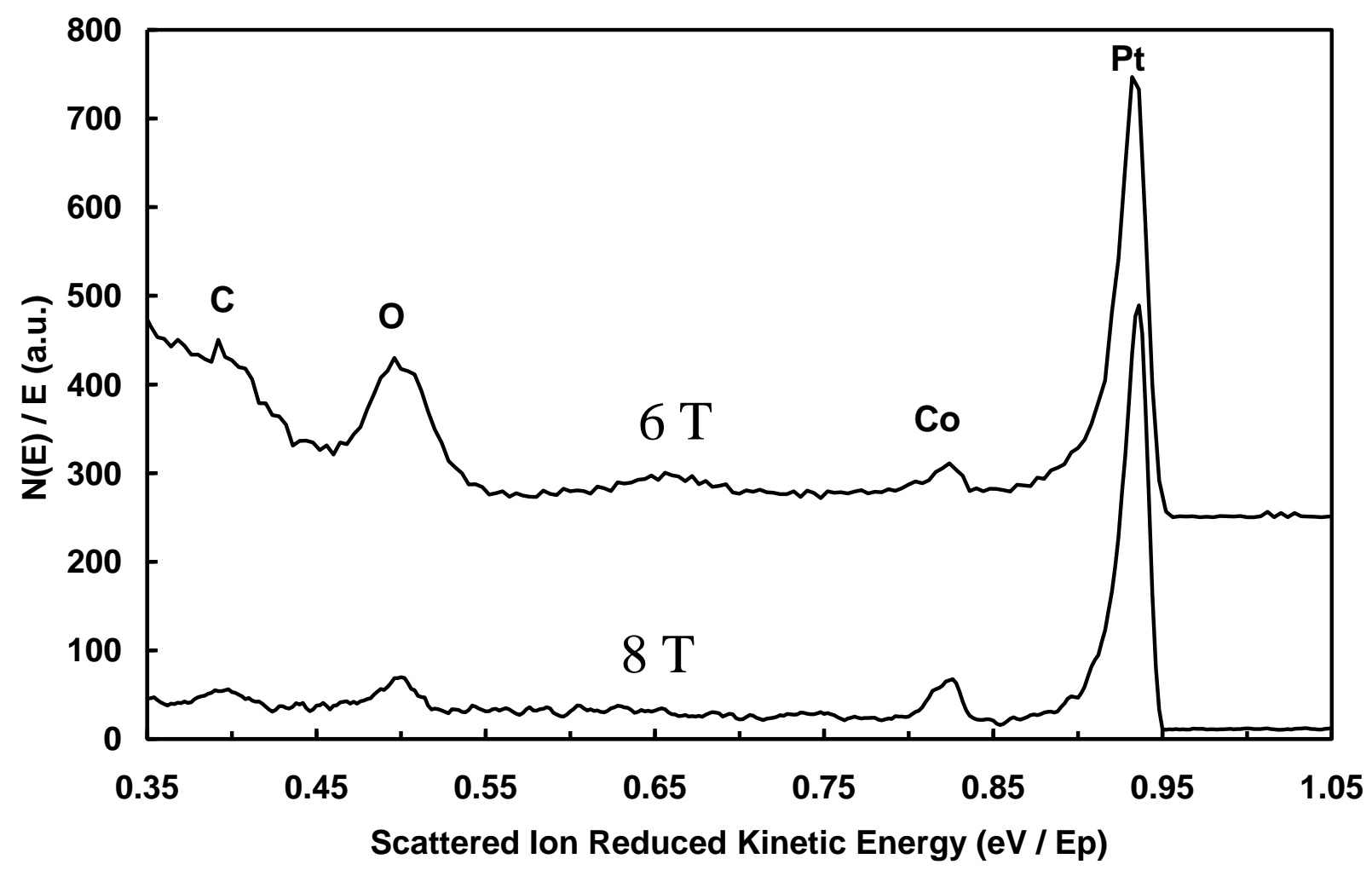

Fig. 5 


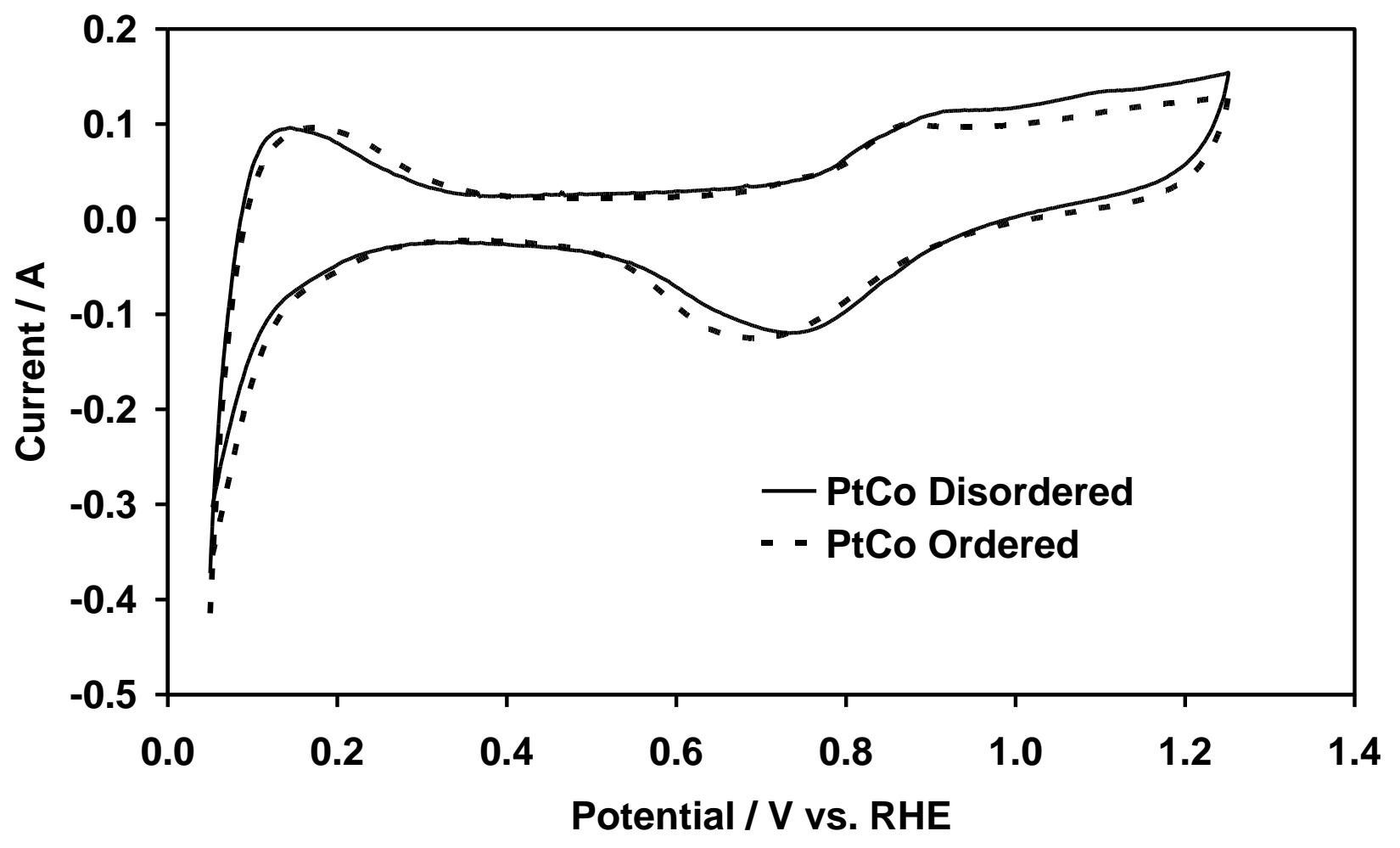

Fig. 6 

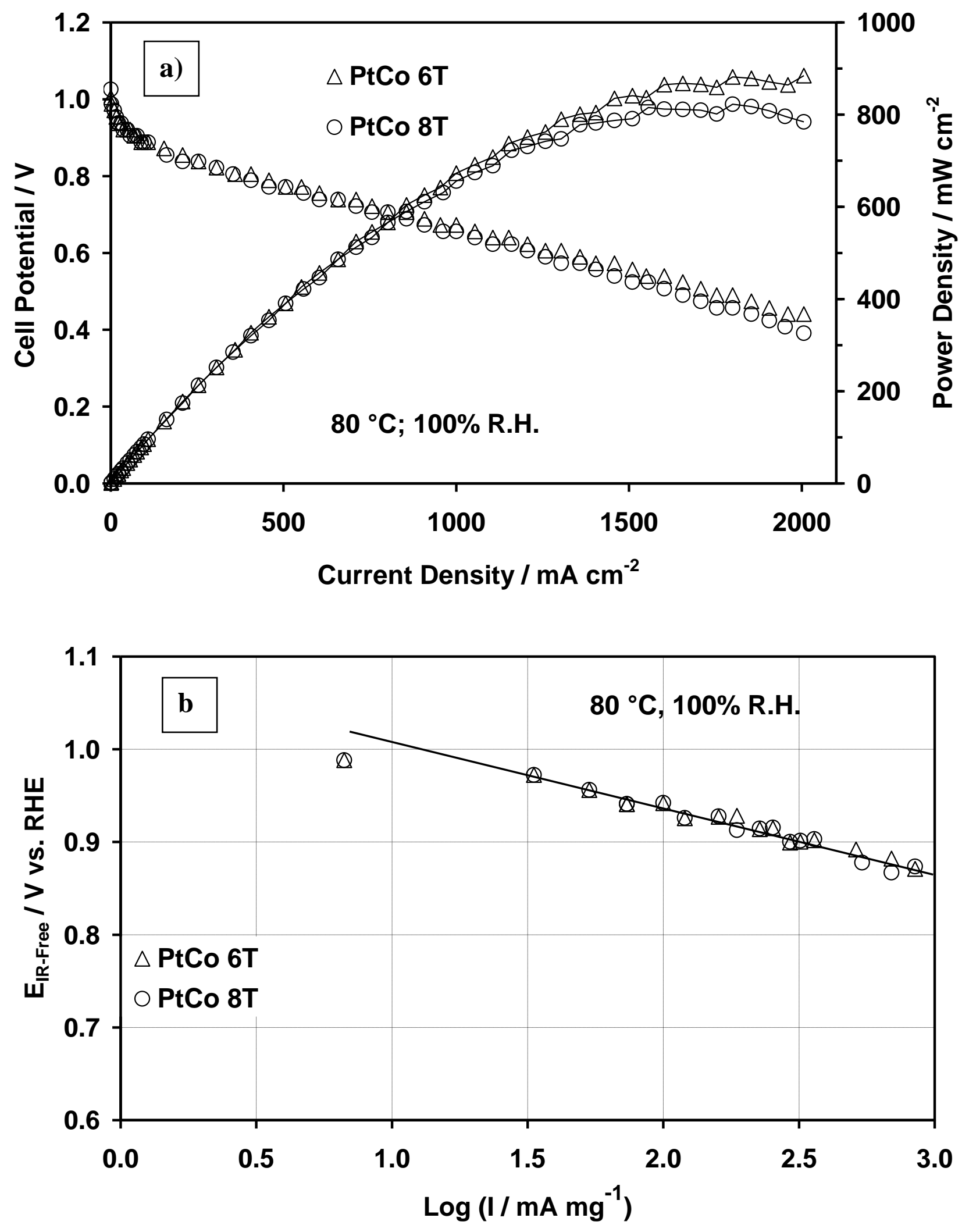

Fig. 7 

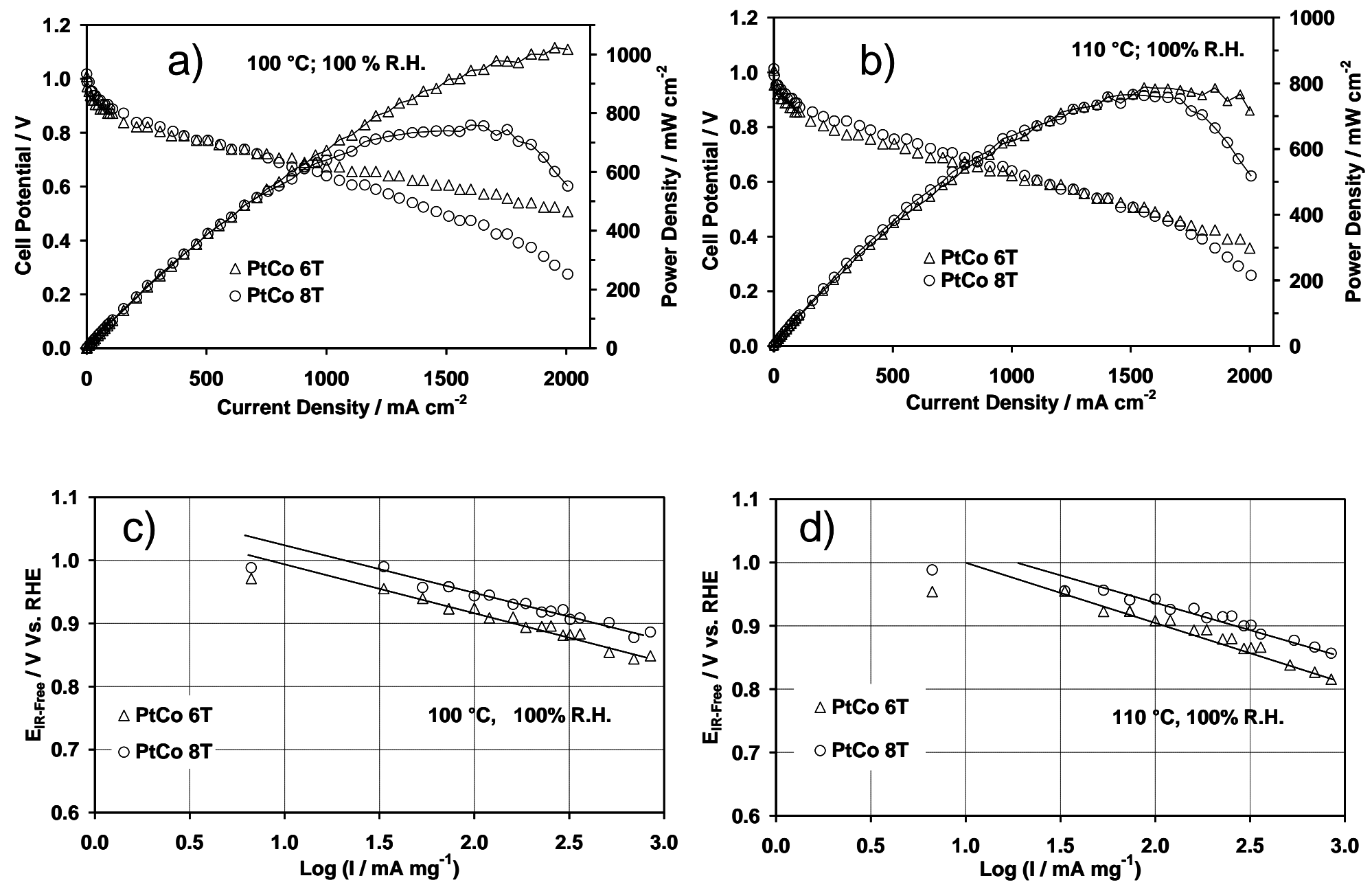

Fig. 8 

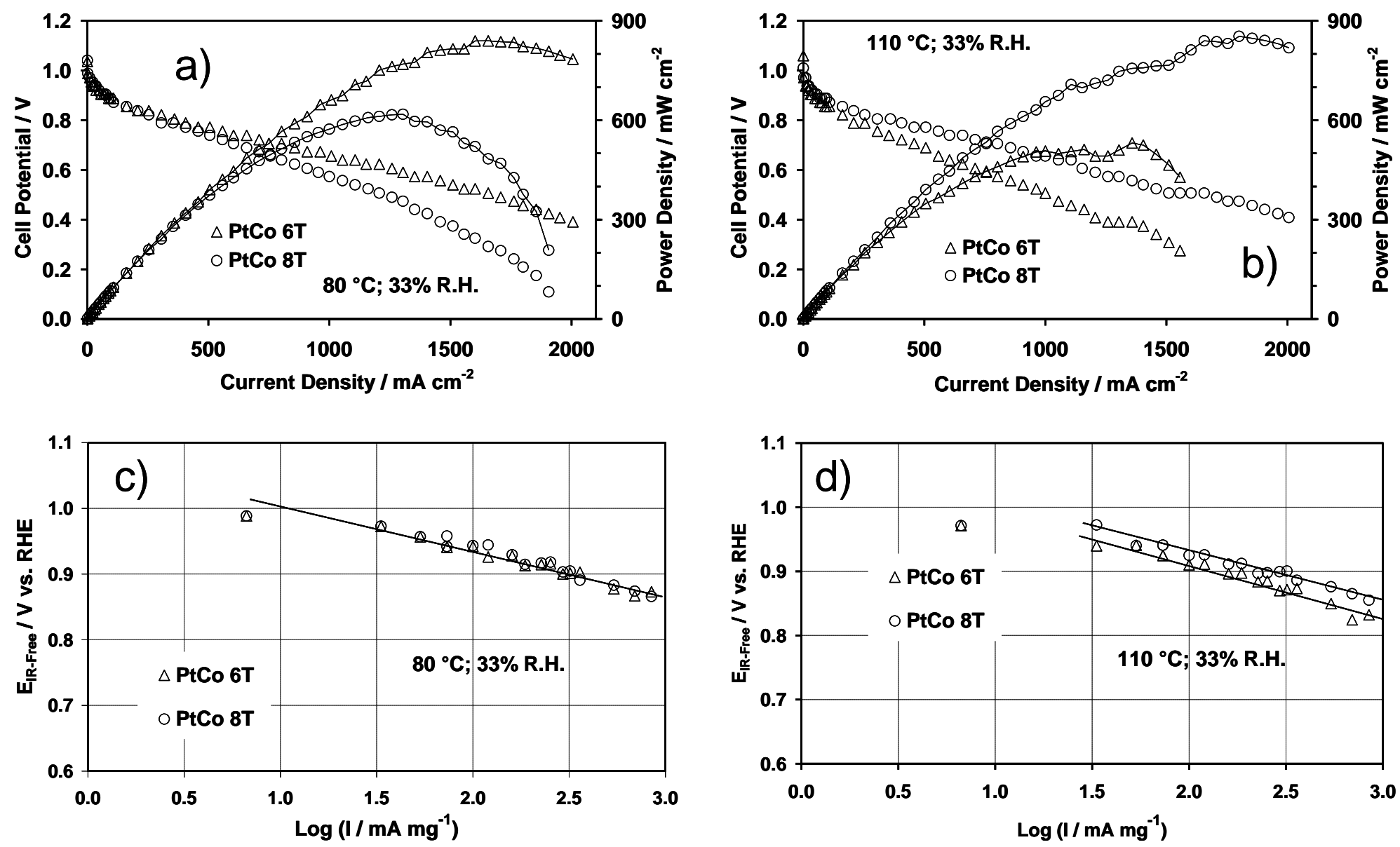

Fig. 9 


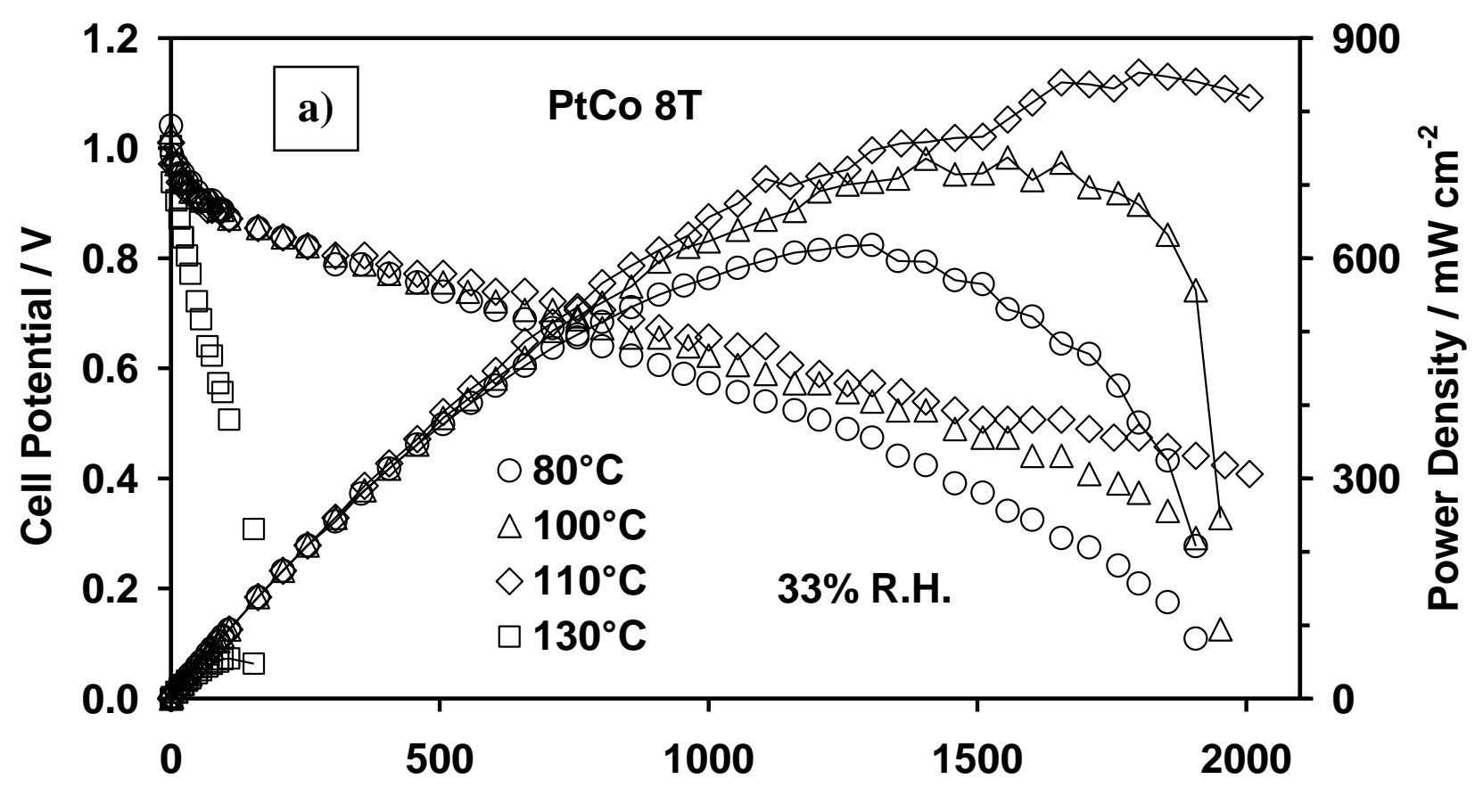

Current Density / $\mathrm{mA} \mathrm{cm}{ }^{-2}$

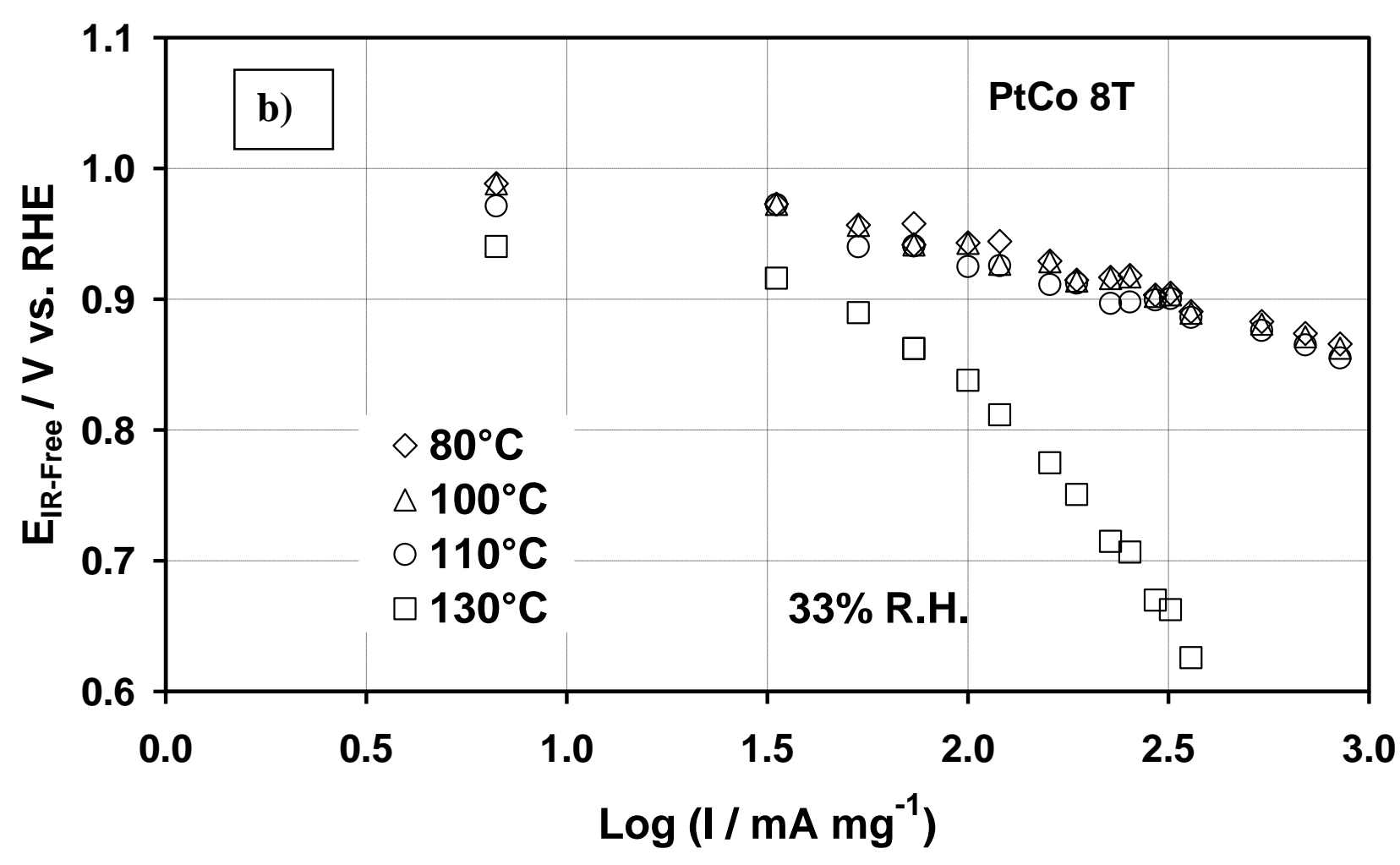

Fig. 10 


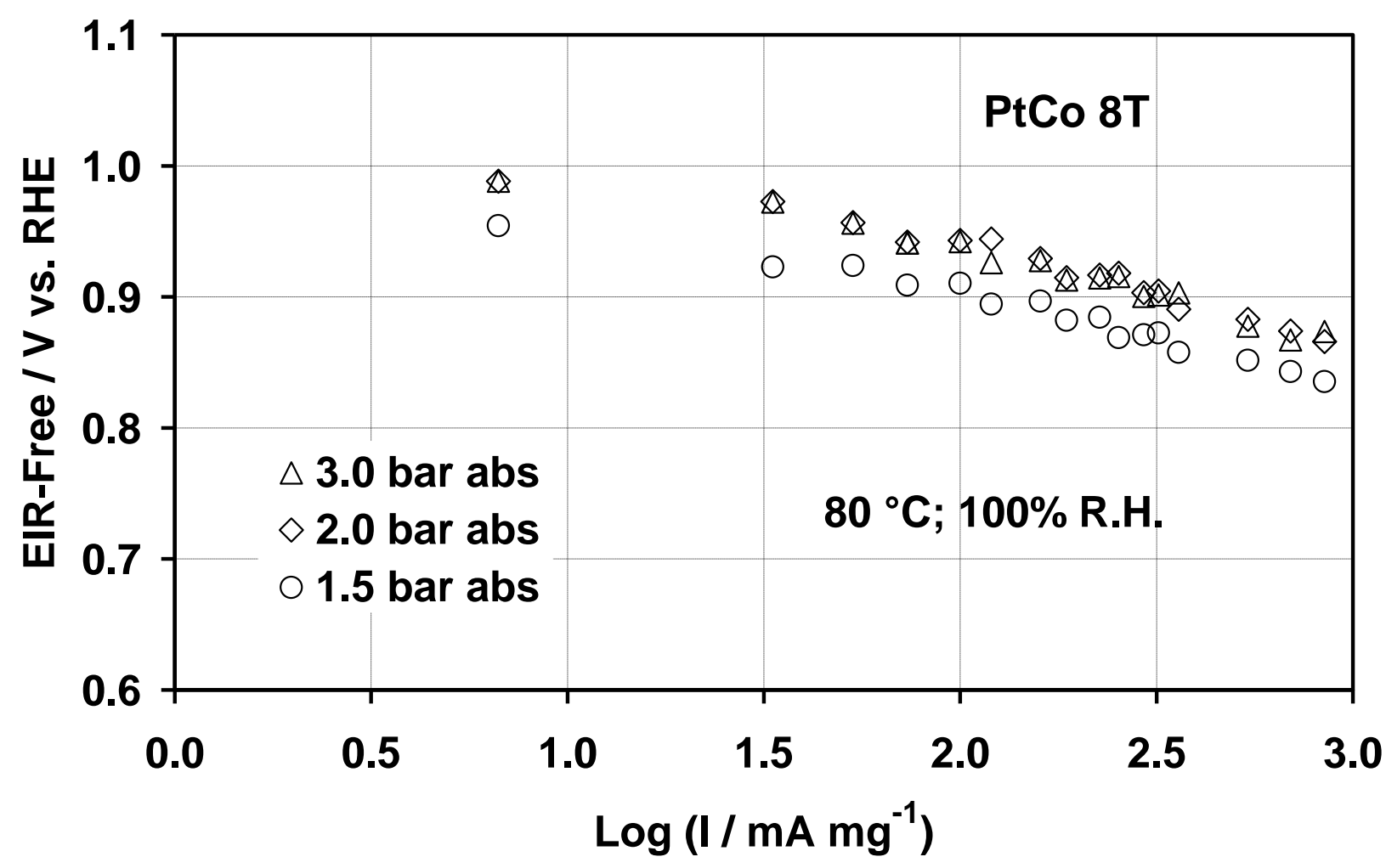

Fig. 11 

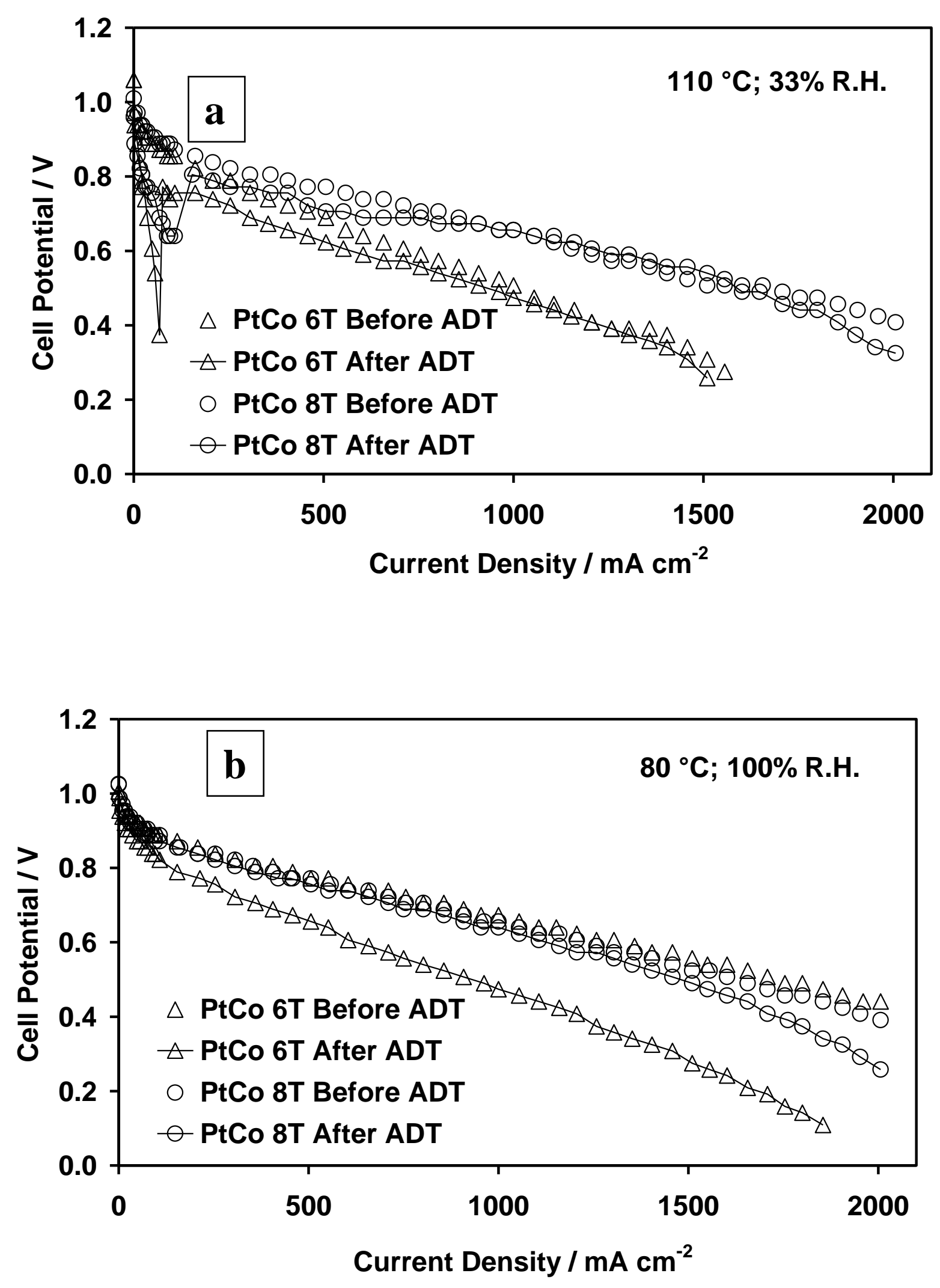

Fig. 12 

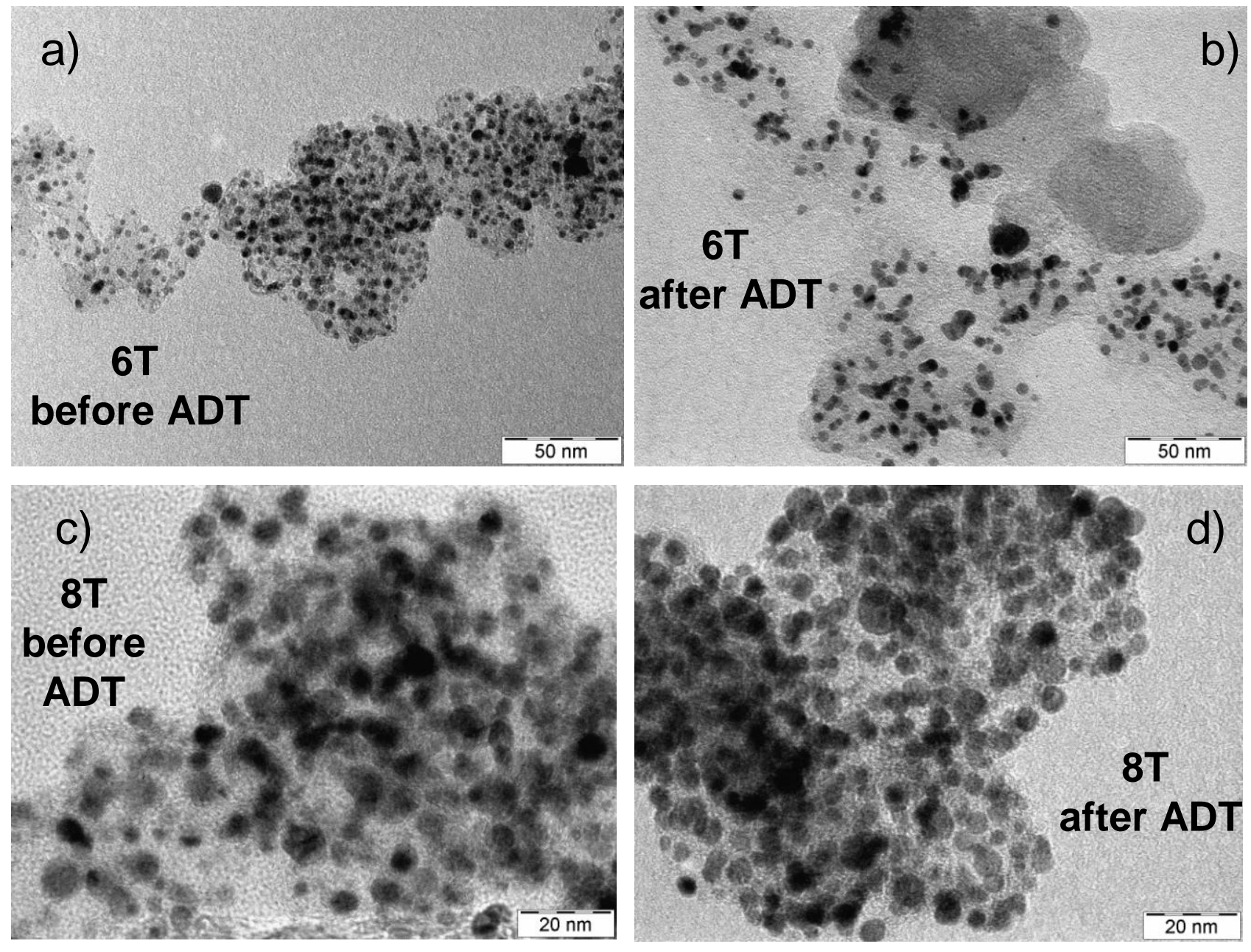

Fig. 13 

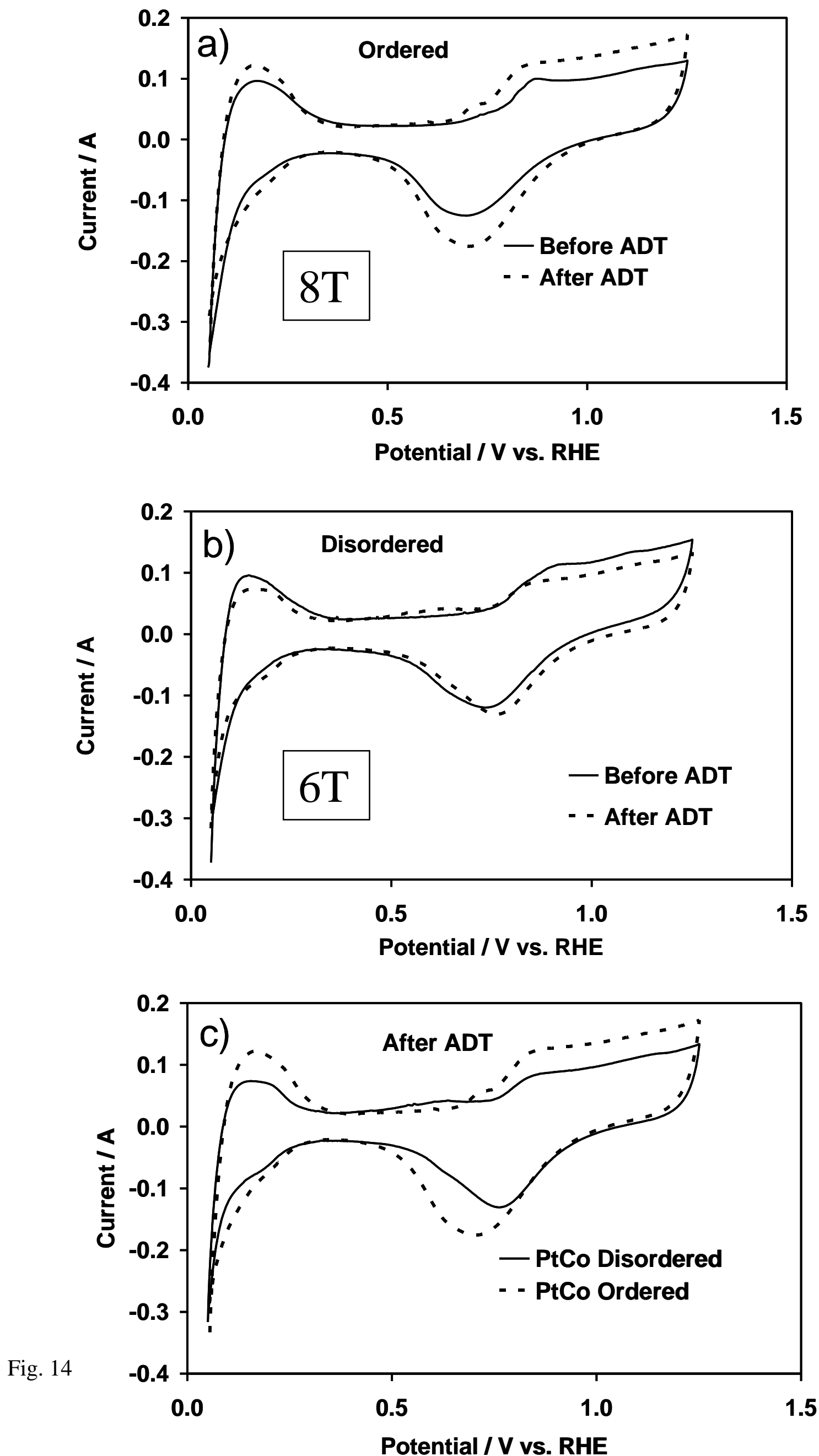

Potential / V vs. RHE 